IZA DP No. 5948

Search, Effort, and Locus of Control

Andrew McGee

Peter McGee

August 2011

Forschungsinstitut

zur Zukunft der Arbeit

Institute for the Study

of Labor 


\title{
Search, Effort, and Locus of Control
}

\author{
Andrew McGee \\ Simon Fraser University \\ and IZA \\ Peter McGee \\ National University of Singapore \\ Discussion Paper No. 5948 \\ August 2011 \\ IZA \\ P.O. Box 7240 \\ 53072 Bonn \\ Germany \\ Phone: +49-228-3894-0 \\ Fax: +49-228-3894-180 \\ E-mail: iza@iza.org
}

Any opinions expressed here are those of the author(s) and not those of IZA. Research published in this series may include views on policy, but the institute itself takes no institutional policy positions.

The Institute for the Study of Labor (IZA) in Bonn is a local and virtual international research center and a place of communication between science, politics and business. IZA is an independent nonprofit organization supported by Deutsche Post Foundation. The center is associated with the University of Bonn and offers a stimulating research environment through its international network, workshops and conferences, data service, project support, research visits and doctoral program. IZA engages in (i) original and internationally competitive research in all fields of labor economics, (ii) development of policy concepts, and (iii) dissemination of research results and concepts to the interested public.

IZA Discussion Papers often represent preliminary work and are circulated to encourage discussion. Citation of such a paper should account for its provisional character. A revised version may be available directly from the author. 
IZA Discussion Paper No. 5948

August 2011

\section{ABSTRACT}

\section{Search, Effort, and Locus of Control}

We test the hypothesis that locus of control - one's perception of control over events in life influences search by affecting beliefs about the efficacy of search effort in a laboratory experiment. We find that reservation offers and effort are increasing in the belief that one's efforts influence outcomes when subjects exert effort without knowing how effort influences the generation of offers but are unrelated to locus of control beliefs when subjects are informed about the relationship between effort and offers. These effects cannot be explained by locus of control's correlation with unmeasured human capital, personality traits, and the costs of search - alternative explanations for the relationships between locus of control and search behavior that cannot be ruled out using survey data - as the search task does not vary across treatments, which leads us to conclude that locus of control influences search through beliefs about the efficacy of search effort. Our findings provide evidence that locus of control measures can be used to identify job seekers at risk of becoming "discouraged" and abandoning search.

JEL Classification: J64, D83, C91

Keywords: locus of control, reservation wages, labor market search, experiment

Corresponding author:

Andrew McGee

Department of Economics

Simon Fraser University

8888 University Drive

Burnaby, BC V5A 156

Canada

E-mail: andrew_mcgee@sfu.ca 


\section{Introduction}

Few personality traits studied by psychologists have generated as much interest among economists as locus of control, one's beliefs concerning the relationship between one's actions and outcomes in life (Rotter 1966). Individuals with an external locus of control believe that outcomes are primarily matters of fate or chance. At the other extreme of this continuum of beliefs, individuals with an internal locus of control believe outcomes depend primarily on their own efforts. Easily measured and recorded in surveys including the National Longitudinal Surveys of Youth (NLSY) and the German Socio-Economic Panel (GSOEP), locus of control is correlated with important economic outcomes such as earnings (Andrisani 1977, 1981; Goldsmith, Veum, and Darity 1997; OsborneGroves 2005), educational attainment (Coleman and DeLeire 2003; Baron and Cobb-Clark 2010; Piatek and Pinger 2010), and unemployed job search (Caliendo, Cobb-Clark, and Uhlendorff 2010; McGee 2010). In spite of the widespread interest in locus of control and its obvious importance, how locus of control influences behavior is not well understood given the limitations of survey data. While psychologists envision locus of control influencing behavior through beliefs about the efficacy of effort, the documented effects of locus of control could result from its correlation with unobserved dimensions of human capital, personality, and effort costs.

In this study, we aim to identify the mechanism through which locus of control influences behavior. Specifically, we examine the relationship between locus of control and search behavior in a laboratory experiment in which subjects "search" by exerting effort that influences the stochastic process by which monetary offers are generated. Key to our study is the fact that the laboratory allows us to control what subjects know about the return to effort. Subjects "search" in a limited information treatment in which the benefit to their effort is not made clear to them followed by a full information treatment in which the relationship between effort and the process by which offers are 
generated is fully explained to them. We hypothesize that in the limited information treatment internal individuals who believe their actions influence outcomes will believe the rate of return to effort to be higher than their less internal peers and exert more effort searching and set higher reservation offers. We expect locus of control to have no effect on behavior in the full information treatment when there is no uncertainty about the relationship between effort and outcomes. Our approach allows us to rule out the competing explanations for the role of locus of control. We control for a wider variety of psychological characteristics than are generally found in survey data, and the real effort task is the same in both the limited and full information treatments such that if locus of control's effect stems from its correlation with unobserved dimensions of human capital, personality, or effort costs then its effect on search behavior should not vary across treatments.

The experimental design is straightforward. Subjects participated in search episodes lasting for 21 periods. All subjects began a search episode in possession of an outside option which they earned in any period in which they had not accepted an offer through the $20^{\text {th }}$ period. In each period, subjects had the opportunity to perform tasks - the experimental analog of search effort-that increased the probability that they receive an offer. If an offer was received, subjects decided whether to accept the offer and receive that amount in each subsequent period (i.e., their search ends) or refuse the offer and search again in the next period. In the limited information treatment, subjects were not informed of the relationship between completed tasks and the probability of receiving an offer, while in the full information treatment they were made aware that each completed task increased the probability of receiving an offer by four percentage points. The distribution of potential offers was common knowledge in all search episodes. In periods during which a subject searched in the limited information treatment, the subject was asked what he/she believed the probability that an offer would be received was, and subjects reported in both treatments in periods involving search 
their reservation offer before learning whether they received an offer. Finally, subjects completed a survey collecting information on the subject's background, locus of control, risk preferences, and personality traits using standard measures found in survey data.

In section II, we present a search model in which locus of control influences beliefs about the efficacy of search effort. More internal individuals believe themselves more likely to receive an offer conditional on any amount of effort than less internal searchers; they set higher reservation offers as a result. Likewise, more internal individuals perceive the marginal benefit to search effort to be higher than less internal individuals and exert more effort as a result. Consistent with these predictions, we find that reservation offers and effort are positively related to internality in the limited information treatment. A one-standard deviation increase in internality is associated with an estimated increase in reservation offers of 1.2 experimental currency units (ECUs) and an estimated increase of 0.9 items completed in a sample in which offers range from 5 to 45 ECUs and subjects average nearly 10 items completed per period. By contrast, we find no evidence that locus of control is related to reservation offers or items completed in the full information treatment.

McGee (2010) and Caliendo et al. (2010) find that internality is positively related to search effort and reservation wages among unemployed job seekers using the NLSY79 and GSOEP, respectively. More internal job seekers, however, may expend more effort and hold out for higher wages because they are, in fact, better at searching or because they know that skills correlated with locus of control and unobserved by econometricians make them more desirable to employers than less internal individuals. Alternatively, more internal individuals may be less bothered by expending effort on search. These alternative explanations for the correlations between locus of control and search behavior cannot generally be ruled out using survey data, but they also cannot explain the differences observed across treatments in our experiment. Given that the only difference between the 
treatments is what the subjects know about the return to effort, an effect of locus of control on beliefs about the efficacy of effort can explain these observed differences in behavior.

Studying the connection between beliefs about the return to effort and job search is, in part, motivated by the phenomenon of discouraged workers who enter long-term non-employment because they no longer believe that they can find a job (Schweitzer \& Smith 1974). Surprisingly, discouragement presents itself in this short experiment as in $29 \%$ and $12 \%$ of subject-period observations in the limited and full information treatments, respectively, subjects "quit" in that they either choose to complete no tasks or stop attempting tasks before their time allotment expires. This phenomenon is strongly related to subjects' locus of control as more external individuals are substantially more likely to "quit" than their more internal peers.

Our findings contribute to the growing labor literature studying the relationships between personality and "soft" skills and labor market outcomes, but the study also contributes to a wellestablished literature concerning experimental labor markets. As articulated in Falk and Fehr (2003), the laboratory provides an excellent methodological tool because it affords the experimenter control over a number of aspects of the labor market environment. Early studies with exogenous offer arrival rates (Braunstein \& Schotter 1981, 1982; Cox \& Oaxaca 1989) exploited this control to demonstrate that the predictions of job search models with respect to reservation wages are borne out in the laboratory. Recent experimental studies have investigated how factors beyond the scope of standard job search models such as wait times (Brown et al. 2011) and self-image (Falk et al 2006) influence subjects' search choices. In this vein, ours is the first study to leverage the control afforded by the laboratory to examine the effects of locus of control on search.

From a policy point of view, our findings have two important implications. First, we show in an additional treatment that providing searchers with information concerning the experiences of past 
searchers—-how much effort they exerted and whether they received an offer—can reduce searchers' reliance on locus of control beliefs that may introduce a behavioral bias causing them to search too little or hold out for excessively high wages. This suggests that fairly minimal counseling for the unemployed can be welfare-enhancing. Second, our findings indicate that programs supporting unemployed job seekers can identify individuals at risk of becoming discouraged and exiting the labor market using simple measures of locus of control beliefs.

While we have labor market search in mind, our findings in the abstract laboratory setting provide insight into how locus of control will affect decision-making in settings ranging from investment behavior to spousal search to consumer search. Specifically, our findings suggest that in any setting requiring effort choices in which the return to effort is uncertain, locus of control will influence both how much effort the individual exerts and how selective the individual is-insights which have important practical implications. For instance, marketers and internet dating sites might wish to target external individuals who would otherwise exert less effort searching on their own. Marketers may want to "de-bias" internal individuals to induce them to purchase rather than holding out for a "steal." While locus of control undoubtedly affects behavior in these settings, determining how is only possible through an experimental study such as ours.

\section{Search Model}

We model search over a finite horizon $(t=1,2, \ldots, 21)$ with endogenous search effort determining the probability of receiving an offer in any period. Searchers receive an outside offer (a search subsidy), $w^{0}$, in every period in which they have not previously accepted an offer received through their search through the $20^{\text {th }}$ period; they receive nothing in the $21^{\text {st }}$ period if they have not accepted an offer. The offers $w_{t}$ are drawn from a discrete distribution in which $w_{t} \in\left\{w^{1}, w^{2}, w^{3}, w^{4}, w^{5}, w^{6}, w^{7}\right\}$ and $\sum_{i=1}^{7} \operatorname{Pr}\left(w^{i}\right)=1$. In any period before an offer has been 
accepted, the individual chooses how much effort to exert $s_{t} \in\{0,1, \ldots, \bar{S}\}$ and a reservation offer $w_{t}^{r}$ such that only offers greater than or equal to $w_{t}^{r}$ are accepted. If an offer is accepted in period $t$, the subject receives this amount in every period from $t+1$ through and including the $21^{\text {st }}$ period. The effort exerted determines the probability that an offer is received:

$$
\operatorname{Pr}\left(\text { Offer }_{t}=1\right)=\lambda s_{t} \text { if } s_{t}<\frac{1}{\lambda} \text { and } 1 \text { otherwise }
$$

where $O \mathrm{ffer}_{t}=1$ indicates that an offer is received in period $t$ and $\lambda$ represents the productivity of search effort. The costs of search effort are given by $c\left(s_{t}\right)$ where $c^{\prime}>0, c^{\prime \prime}>0$. The period utility given an offer $w$ in hand is $u(w)$, and we assume that $u(0)=0$ and $c(0)=0$. For convenience, we assume that individuals do not discount future periods.

The searcher chooses effort and a reservation offer to maximize the present value of search

$$
\begin{aligned}
& V_{t}^{S}=u\left(w^{0}\right)-c\left(s_{t}\right)+\lambda s_{t} \operatorname{Pr}\left(w \geq w_{t}^{r}\right)(21-t) E\left\{u(w) \mid w \geq w_{t}^{r}\right\} \\
& +\left(1-\lambda s_{t} \operatorname{Pr}\left(w \geq w_{t}^{r}\right)\right) V_{t+1}^{S}
\end{aligned}
$$

Given that $V_{21}^{S}=0$, this maximization problem can be solved recursively in a straightforward fashion, but solving for this solution is complicated by the fact that the cost of real effort is known only to the individual, an issue we discuss in the next section.

We assume, however, that individuals are uncertain about the return to search effort, $\lambda$, and choose search effort and reservation offers to maximize instead

$$
\begin{gathered}
E\left(V_{t}^{S}\right)=u\left(w^{0}\right)-c\left(s_{t}\right)+E\left\{\lambda \mid\left\{s_{j}\right\}_{j=1}^{j=t},\left\{\text { offer }_{j}\right\}_{j=1}^{j=t}, X\right\} s_{t} \operatorname{Pr}\left(w \geq w_{t}^{r}\right)(21-t) E\{u(w) \mid w \\
\left.\geq w_{t}^{r}\right\}+\left(1-E\left\{\lambda \mid\left\{s_{j}\right\}_{j=1}^{j=t},\left\{\text { offer }_{j}\right\}_{j=1}^{j=t}, X\right\} s_{t}\right) \operatorname{Pr}\left(w \geq w_{r}^{t}\right) V_{t+1}^{S}
\end{gathered}
$$

where the individual's subjective estimate of the return to effort, $E\left\{\lambda \mid\left\{s_{j}\right\}_{j=1,}^{j=t},\{\text { offer }\}_{j=1,}^{j=t}, X\right\}$, depends on prior search effort choices, outcomes, and individual characteristics $X$ that inform the individual's prior regarding the return to search effort. As individuals acquire search experience, they 
should update away from this prior based on their experiences, but the factors $X$ will have a persistent effect on behavior to the extent that prior beliefs continue to affect behavior. Among the characteristics included in $X$ is an individual's locus of control. Similar to the labor contracts model of Bowles et al. (2001), we assume that an individual's subjective estimate of the return to search

effort is increasing in one's sense of control, internality. That is, $\frac{\left.\partial E\left\{\lambda \mid\left\{s_{j}\right\}_{j=1}^{j=t},\{\text { offer }\}_{j}\right\}_{j=1}^{j=t}, X\right\} \text {, }}{\partial \text { locus }}>0$, where locus is increasing in internality. The model's key testable predictions are that more internal individuals will exert greater effort in each period and hold out for higher reservation offers than less internal individuals (see McGee (2010) or Caliendo et al. (2010) for derivations of these predictions in similar settings). More internal searchers expect to receive an offer with higher probability conditional on any amount of search effort than less internal searchers, so they hold out for higher offers. Similarly, more internal searchers believe the marginal return to search effort to be higher than less internal searchers, so they exert more effort.

\section{Experimental Design and Data}

Subjects were undergraduate students at The Ohio State University randomly invited to participate in sessions lasting just over two hours each. In each session, subjects participated in 2-4 search episodes and completed a short questionnaire. Subjects were informed that each search episode would last 21 periods, that they would only earn experimental currency units (ECUs) in the $21^{\text {st }}$ period of a search episode if they had accepted an offer in an earlier period, that they would earn the outside option (15 ECUs) in every period prior to accepting an offer (except for the $21^{\text {st }}$ period), and that at the end of the experiment earnings in ECUs would be converted to dollars at a rate of 100 ECUs to $\$ 1$. Offers generated by search effort were drawn from the discrete distribution with seven points of support described in table 1, and this distribution was explained to subjects in the instructions (provided in the Appendix) prior to the experiment. 
At the beginning of each period before an offer had been accepted, subjects "searched" by performing a coding task. Subjects were given a key matching ten words to ten four-digit numbers. The key was followed by seven multiple choice questions, each listing a word and five four-digit numbers with the correct answer being the four-digit number corresponding to the word in the key. After completing a set of seven questions, subjects moved on to a new set of word-number pairings and questions ("items"). Screenshots of the interface used by subjects in the limited information and full information treatments are provided in figures $1 \mathrm{a}$ and $1 \mathrm{~b}$, respectively. Subjects had 90 seconds to correctly code as many items as they could, though they were not required to complete any items and could either complete no items or exit the coding task and move on if they so chose. We use the coding task because of the limited skill involved: subjects need only to be able to read as the correct answer to every question is given in the key. While there are likely modest differences among subjects in their ability to navigate the interface and code items, we assume that differences in the number of items coded reflect differences in effort exerted rather than differences in ability.

The number of items correctly coded in a period determines the probability of receiving an offer in that period. In all treatments, each item correctly coded increases the probability of receiving an offer by four percentage points, i.e.,

$$
\operatorname{Pr}\left(\text { offer }_{t}=1\right)=\left\{\begin{array}{c}
0.04 *(\# \text { of items completed }) \text { if } \# \text { of completed items } \leq 25 \\
1 \text { otherwise }
\end{array}\right.
$$

In the limited information search episode, subjects were not told how correctly coded items affected the probability of receiving of an offer. Subjects were told that, "The number of items you complete in the word coding task may affect whether or not you receive an offer during a period." In the full information treatment, subjects were explicitly informed of the relationship between correctly coded items and the probability of receiving an offer. Following the coding task in the limited information treatment, subjects were asked three questions. First, "How many items do you think you correctly 
completed?" Second, "What do you think the probability is that you receive an offer? Please enter a number between 0 and 100, where 0 means that you will definitely not receive an offer and 100 means that you definitely will receive an offer." Third, "If you receive an offer in this period, what would the offer have to be for you to accept it?" We use this measure of self-reported reservation offers to generate data comparable to the reservation wage data found in surveys such as the NLSY79 and GSOEP elicited using similarly worded questions.

After answering these questions, subjects learned whether they had received an offer and the amount of the offer if one was received. Subjects who received an offer were asked if they wished to accept the offer and receive it in all remaining periods. If subjects accepted an offer, their search episode ended. If they did not receive an offer or declined an offer, they moved to the next period and repeated this process, beginning with the coding task. Subjects moved from period to period until they had accepted an offer. If no offer had been accepted by the end of the twentieth period, the search episode ended and subjects were paid the outside option for 20 periods. The full information treatment proceeded in the same fashion, but subjects were not asked their beliefs about the probability of receiving an offer.

Subjects in all sessions completed the limited and full information treatments with the limited information search episode always coming first. Subjects in some sessions also completed one of two additional treatments. In the partial information treatment, subjects were provided information concerning the experiences of prior subjects. Specifically, subjects were told how many items 60 subjects had completed, whether the subject received an offer, and the amount of the offer if one was 
received. The information sheet given to subjects is provided in Figure 2. ${ }^{1}$ In all other respects, the partial information treatment was exactly the same as the limited information treatment, and subjects always completed the partial information treatment between the limited information and full information treatments. In limited and full information "pseudo-effort" treatments, subjects purchased items instead of completing the coding task. The relationship between items purchased and the probability of receiving an offer was the same as in the real-effort treatments: each item purchased increased the probability of receiving an offer by four percentage points. In the pseudoeffort limited information treatment, subjects were told that the number of items purchased "may affect" whether an offer would be received, while in the full information pseudo-effort treatment subjects were told exactly how items purchased affected the probability of receiving an offer. The costs of purchasing $n$ items was $0.10 n^{2}$, and the user-interface allowed subjects to calculate the costs of any number of items they were considering purchasing. Costs incurred over the course of a search episode were deducted from the subject's show-up fee. Subjects completing the pseudo-effort treatments completed four search episodes: the limited and full information real effort treatments and the limited and full information pseudo-effort treatments. The limited information real and pseudo effort treatments always preceded the full information treatments, but we varied the order of the pseudo and real effort treatments across sessions. ${ }^{2}$

After completing the search episodes, subjects completed a questionnaire including the abbreviated, four-item Rotter Internal-External Locus of Control Scale used in the NLSY79

\footnotetext{
${ }^{1}$ While the sample of prior experiences provided to subjects was drawn randomly from the actual experiences of prior subjects, we selected a sample in which a regression of whether an offer was received on items completed resulted in an estimated slope of approximately 0.04 .

${ }^{2}$ We observe no differences related to the orderings of the real and pseudo effort treatments.
} 
measuring general locus of control beliefs (Rotter, 1966), a fifty-item Big Five inventory measuring extraversion, agreeableness, conscientiousness, emotional stability, and imaginativeness or intellect (Goldberg, 1992), the Rosenberg Self-Esteem Scale (Rosenberg, 1965), and the Life Orientation Test-Revised designed to assess individual differences in generalized optimism versus pessimism (Scheier et al., 1994). In addition, subjects completed the low-stakes risk preference measure from Holt and Laury (2002) used in the experimental literature and risk preference measures from the GSOEP and the Health and Retirement Survey (HRS) (also used in the NLSY79). Finally, subjects were asked how much they would pay to avoid having to complete $4,8,12,16,20$, and 24 coding items as well as questions concerning demographics and achievement test scores.

For the personality measures and achievement scores, we standardize the variables within the sample to have mean zero and standard deviation one to facilitate comparisons of the effects of the different measures on behavior. To create a measure of how onerous or costly the subjects find the coding task, we rank the subjects according to the cost they report for completing a given number of items. The cost measure then takes the average decile for the subject's responses to the 8 -item, 12 item, and 16-item cost questions. ${ }^{3}$ The questionnaire components are provided in the Appendix.

The sessions are summarized in table 2 . Subjects were paid a flat $\$ 6$ show up fee in addition to their earnings from each search episode and the Holt-Laury instrument. In total, 155 subjects provided 1,410 subject-period observations in the limited information real effort treatment and 1,287 subject-period observations in the full information real effort treatment.

Table 3 details the mean reservation offer and number of items correctly completed by period in the limited and full information treatments as well as the theoretically optimal choices in a full

\footnotetext{
${ }^{3}$ Alternative methods of constructing the self-reported cost measure produced results similar to those reported in section $\mathrm{V}$.
} 
information setting for risk-neutral searchers $(u(w)=w)$ whose search effort costs are given by $c\left(s_{t}\right)=-0.10 s_{t}^{2} \cdot{ }^{4}$ Reservation offers decrease significantly over time in both the limited and full information treatments, which is consistent with the theoretical prediction in a finite horizon and Cox and Oaxaca's (1989) findings in a laboratory experiment without endogenous search effort. While the model predicts that search effort will decline over time, search effort is relatively constant in both treatments, which may reflect the imposition of the 90 -second time limit, a practical necessity. The average number of items completed is higher in the full information treatment than in the limited information treatment in all 20 periods. In the early periods, this may be a result of the subjects' inexperience with the coding task in the limited information treatment, but the persistence of the difference suggests that subjects exert more effort on average when the return to effort is certain.

Table 4 reports the summary statistics for the control variables and the demographic composition of our sample. In the regression analysis, we use standardized versions of the control variables, but table 4 reveals substantial variation in the underlying raw scores-especially locus of control scores which range from 6 to 16 with a standard deviation of 2.43. Not all subjects reported ACT and SAT scores. When constructing the standardized achievement measure used in section V, we use the ACT score when available and then supplement with the average of available SAT scores when the ACT score is missing.

\footnotetext{
${ }^{4} \mathrm{We}$ estimate a cost function in terms of ECUs of $c\left(s_{t}\right)=-7.0+5.0 s_{t}+0.3 s_{t}^{2}$ using subjects' selfreported costs of completing items, which appears to dramatically overstate costs as in the full information setting it would imply zero effort in all periods. Subjects, who report costs in dollars, may have difficulty articulating costs prior to receiving their earnings. The prediction of declining reservation wages over time, however, does not depend on the exact shape of the cost function, and the self-reported costs indicate that the cost function is at least quasi-convex for all subjects.
} 
A particular strength of our study is that we observe a large set of personality traits, and table 5 documents the pairwise correlations between these traits, risk preferences and locus of control. Internality is significantly and positively correlated with optimism (0.34), self-esteem (0.38), extroversion (0.33) and conscientiousness (0.30). As one could imagine a role for all of these traits in search, controlling for them is necessary to identify the direct effects of locus of control. For example, a searcher may believe that the probability of receiving an offer is equal to $a+\lambda s_{t}$, where $a$ is the probability of receiving an offer independent of effort. As a searcher's expectation regarding $a$ increases, the searcher will hold out for higher offers, but search effort will not be affected as the marginal return to search effort remains the same. If general optimism is positively correlated with beliefs about $a$, then omitting optimism would introduce a positive omitted variables bias in the estimated coefficient of locus of control in reservation wage models.

\section{Econometric Strategy}

Our primary hypotheses are that locus of control influences beliefs about the efficacy of search effort and that these beliefs, in turn, influence actual search behavior. To test whether locus of control influences beliefs about the return to search effort in the limited information treatment, we estimate by OLS

$$
\operatorname{SubjProb}_{i}\left(\text { Offer }_{t}=1\right)=\beta_{0}+\beta_{1} \text { Locus }_{i}+X_{i} \beta_{2}+\beta_{3} t+\epsilon_{i t}
$$

where $\operatorname{SubjProb}_{i}\left(\mathrm{Offer}_{t}=1\right)$ denotes subject $i$ 's self-reported estimate of the probability of receiving an offer in period $t$ when the subject is still searching, Locus $s_{i}$ the subject's locus of control score, and $X_{i}$ a vector of measures of self-esteem, generalized optimism, risk preferences, personality traits and self-reported effort costs. We allow for a linear time trend in beliefs by including $t$, and $\epsilon_{t}$ is 
the stochastic error term. ${ }^{5}$ If more internal individuals believe the return to search effort to be higher than their less internal peers and complete more items as a result, then the effect of increasing internality $\left(\beta_{1}\right)$ should be positive in this reduced-form specification.

To test how locus of control affects reservation offers, we estimate by OLS for each treatment

$$
\text { ResOffer }_{i t}=\alpha_{0}+\alpha_{1} \text { Locus }_{i}+X_{i} \alpha_{2}+\alpha_{3} t+\epsilon_{i t}
$$

If locus of control influences beliefs about the return to search effort, then individuals will hold out for higher offers and $\alpha_{1}$ should be positive in the limited information treatment and zero in the full information treatment in which subjects face no uncertainty about the return to effort. If, however, internality is positively correlated with ability or negatively correlated with psychic effort costs not captured by our controls, then the effect of increasing internality will be positive in both treatments.

Finally, we estimate by OLS for each treatment

$$
\text { Items }_{i t}=\pi_{0}+\pi_{1} \text { Locus }_{i}+X_{i} \pi_{2}+\pi_{3} t+\epsilon_{i t}
$$

where Items $s_{i t}$ denotes the number of correctly coded items in period $t$. Increasing internality $\left(\pi_{1}\right)$ should be positively related to search effort in the limited information treatment and unrelated to search effort in the full information treatment if locus of control influences effort through beliefs about the efficacy of effort rather than its correlation with ability or effort costs.

In all of the results in the next two sections, we report Huber-White standard errors correcting for the non-independence of observations at the subject level.

\section{Findings}

Subjects clearly believe that the number of items that they correctly complete is related to the probability that they will receive an offer. The estimates in columns 1 and 2 of table 6 indicate that

\footnotetext{
${ }^{5}$ More flexible approaches to modeling the time trends in all of our specifications yielded similar results to those reported in the next section.
} 
subjects' beliefs about the probability of receiving an offer in the limited information treatment are increasing in the number of items they correctly complete allowing for either a linear time trend in beliefs (column 1) or the use of beliefs in the prior period as an "anchor" for beliefs in the current period (column 2). Each correctly completed item is associated with an estimated increase in the probability of receiving an offer of between 0.9 and 1.4 percentage points. While we are interested in how locus of control beliefs influence beliefs about the marginal return to effort, the number items subjects complete is itself a function of locus of locus of control. As such, column 3 reports the results of the reduced-form model of beliefs regarding the probability of receiving an offer detailed in equation 1. We do not find direct evidence of a relationship between self-reported beliefs and locus of control in column 3-although as we report below we find strong evidence that locus of control influences the number of items completed. The effect of locus of control on beliefs is statistically indistinguishable from zero. We do, however, find that subjects' stated beliefs are related to other personality traits. In particular, a one standard deviation increase in optimism is associated with an estimated 5.2 percentage point increase in subjects' reported beliefs about the probability of receiving an offer, while comparable increases in extroversion (Big 1) and conscientiousness (Big 3) are associated with lower reported beliefs regarding the likelihood of receiving an offer.

While we suspect subjects had difficulty articulating their beliefs, they had no such difficulty articulating reservation offers. Subjects' responses to the reservation offer question were non-binding in that they were free to accept an offer less than their reported reservation offer. Nevertheless, subjects adhere to their stated reservation offer policy in $90 \%$ and $89 \%$ of subject-period observations in the limited and full information treatments, respectively, in which the subject received an offer. Furthermore, columns 1,2, and 5 of table 7 make clear that subjects' reservation offers are positively related to their beliefs regarding the probability of receiving an offer in the limited information 
treatment and the number of items completed in both treatments as we would expect. Column 3 reports the estimated marginal effects in the limited information treatment from the reservation offer regression described in equation 2. Consistent with the model's prediction, locus of control is positively related to reservation offers when subjects are uncertain about the return to effort: a one standard deviation increase in internality is associated with a 1.156 ECU increase in reservation offers. By contrast, the estimates for the same model in the full information treatment in column 6 indicate that there is no relationship between locus of control and reservation offers when subjects know exactly how effort affects the probability of receiving an offer.

Columns 4 and 7 report estimates from specifications identical to those in columns 3 and 6 using the $\log$ of the reservation offers as the dependent variable to facilitate comparisons with findings from survey data. ${ }^{6}$ Caliendo et al. (2010) and McGee (2010) find that one standard deviation increases in internality are associated with increases in reservation wages of 1.6 and 1.5 percentage points, respectively. In the limited information treatment, we find that a one standard deviation increase in internality is associated with a 4.9 percentage point increase in reservation offers. The substantially larger effect of locus of control in our experimental setting likely reflects the fact that in real search individuals are typically not wholly ignorant of the job market and understand — in many cases from experience- how their search effort affects outcomes, leaving a circumscribed role for locus of control in determining beliefs about the connection between job search effort and outcomes. In our setting, however, subjects have no idea how effort is related to outcomes and no prior experience to draw upon when forming their expectations. As such, locus of control likely plays a more significant role in determining behavior in our experimental setting than in actual job search.

\footnotetext{
${ }^{6}$ Because some subjects report reservation offers of 0 , these specifications require that we drop a small number of subject-period observations in both treatments.
} 
Two additional interesting facts emerge from table 7. First, risk aversion as measured by the lottery question from the HRS has both a statistically and economically significant negative effect on reservation wages in the limited information treatment. A one standard deviation increase in risk aversion is associated with an estimated 1.8 ECU decrease in reservation offers (a 6.5 percentage point decrease in the log reservation offer specification). Risk averse individuals hedge against the possibility of not getting an offer in subsequent periods by being more willing to accept offers in the current period, and this effect is more pronounced in the environment with more uncertainty- the limited information treatment. Omitting risk preferences from the specification in column 4 results in a $15 \%$ decline in the estimated coefficient of locus of control. Second, we find that reservation wages are positively related an individual's optimism in both treatments-although not statistically significant at conventional levels. One standard deviation increases in optimism are associated with predicted increases of 1.1 ECUs (p-value 0.11) and 1.2 ECUs (p-value 0.17) in the limited and full information treatments, respectively. Omitting the control for optimism-pessimism results in a $21 \%$ increase in the estimated coefficient of locus of control in the limited information treatment because of the positive correlation between internality and optimism.

The evidence from survey data concerning the relationship between search effort and locus of control is limited by the difficulty of measuring job search effort in surveys. That is, should one measure effort using the number of search methods used (e.g., help wanted ads, referrals by friends, placement services), the number of job applications submitted (Caliendo et al. 2010), the number of hours per week spent searching (McGee 2010), or some other measure? By contrast, search effort is well-defined in our experiment, and the relationship in the limited information treatment between locus of control and search effort is among the study's most robust findings. Table 8 reports the estimated marginal effects from the models of the number of correctly completed items in the limited 
and full information treatments detailed in equation 3. When subjects are uncertain regarding the return to effort, internality is positively related to effort: a one standard deviation increase in internality is associated with a predicted increase in items completed of 0.94 items in the limited information treatment but no effect in the full information treatment. Given that subjects average only around 10 items per period, this constitutes a significant increase in effort—-though smaller than the 20 percent increase in hours spent searching per week associated with a one standard deviation increase in internality that McGee (2010) finds. One might suspect that locus of control affects effort because it proxies for diligence or is related to the psychic costs of effort. As noted, however, we control directly for personality traits including conscientiousness and self-reported effort costs. More importantly, the task in both treatments is the same. If the effect of locus of control is not related to the uncertainty surrounding the efficacy of effort, we would not expect to see the differences in the effects of locus of control on reservation offers and effort across treatments that we do.

To explore the role that real effort plays in our findings, we report the estimated marginal effects from the pseudo-effort treatments in table 9. We find no evidence of relationships between locus of control and beliefs, reservation offers, and items purchased in either the limited or full information treatments when subjects simply purchase items. The estimated marginal effect of locus of control on reservation offers in the pseudo-effort limited information treatment (3.369) is large and positive but imprecisely estimated. Locus of control appears to strongly influence search behavior only when uncertainty surrounds the role of real effort. One possible explanation is that subjects learn about the search technology more quickly in the pseudo-effort treatment. In the limited information treatments, the standard deviations of the average number of items completed or purchased are 4.83 and 7.52 in the real-effort and pseudo-effort treatments, respectively. In nine of the first ten periods, the standard deviation of average number items completed or purchased in that 
period in the pseudo effort treatment is higher than — and in most cases twice as large as - - that in the real effort treatment. When uncertain about the return to items completed or purchased, subjects may experiment more when they simply purchase items and do not face the physical constraints in the coding task. Through this experimentation subjects can learn about the search technology more quickly — thereby reducing the importance of their locus of control beliefs.

We also test the robustness of our results to the use of different controls. Our preferred measure of risk preferences is the instrument used in the National Longitudinal Study of Youth 1979 in order to facilitate comparisons between our findings and those from studies using survey data. Table 10 reports the estimated marginal effects in our preferred specifications replacing the risk preference measure from the HRS/NLSY79 with the Holt-Laury risk preference measure. The estimated marginal effects of locus of control are virtually identical to those in table 6-8, although the relationship between locus of control and reservation offers is not significant at conventional levels (p-value 0.119). In results available from the authors, the estimated marginal effects of locus of control in our preferred specifications using the GSOEP risk preference measure are also virtually identical to those in table $6-8$, but the effects of risk preferences are not precisely estimated.

Finally, studies examining the effects of locus of control using survey data typically attempt to control for ability using test scores (e.g., Coleman \& DeLeire 2003; Osborne-Groves 2005). More internal individuals may believe their effort to be more efficacious because it actually is if internality is positively correlated with ability. As such, controlling for ability is important in non-experimental settings. In our analysis, the skill required is the same in both treatments, so we do not expect unobserved ability to lead to an observed difference in the effects of locus of control across treatments. Furthermore, we would argue that including achievement scores as a control for ability in 
our reduced-form specifications is inappropriate as ample evidence suggests that achievement itself is a function of locus of control (Findley \& Cooper 1983).

Nevertheless, we report in table 11 the estimated marginal effects from our preferred specifications in both treatments including our standardized achievement measure as a control. The estimates again indicate that internality is positively related to reservation offers and effort in the limited information treatment. Neither estimate is statistically significant at conventional levels (pvalues of 0.119 and 0.133 , respectively), which is at least in part due to the smaller samples that result from missing achievement scores. The estimated marginal effect of locus of control on reservation offers (1.291) is virtually identical to that reported in table 7 , while the estimated marginal effect on effort (0.571) is roughly $40 \%$ smaller than the estimate in table 8 . We find no evidence of a relationship between locus of control and reservation offers in the full information treatment, and a negative relationship between internality and effort in the full information treatment. Achievement scores are positively related to effort in both treatments, but the differences across treatments in locus of control's effects cannot be explained by a correlation with unobserved ability.

In summary, we are unable to document a direct effect of locus of control on beliefs. We find, however, strong indirect evidence in support of the hypothesis that locus of control influences search behavior through an influence on beliefs about the efficacy of effort. Specifically, we find that reservation offers and effort are positively and significantly related to internality when subjects are uncertain about the efficacy of effort but wholly unrelated to internality when the connection between effort and outcomes is public information. The skill content of the task and the effort required of subjects are the same across treatments - meaning that a correlation between locus of control and unobserved skill or effort costs cannot explain the observed treatment effects.

\section{Extensions}


The evidence in the preceding section suggests that locus of control is closely related to the two decisions all job seekers make-reservation wage and effort choices-that determine the length of unemployment spells. Two extensions to our main results inform how programs can assist the unemployed in a welfare-enhancing fashion and identify job seekers at risk of becoming discouraged and exiting the labor force. First, some job training programs seek to help participants develop a more internal locus of control and increase their general sense of self-efficacy (Dextraze 1986; Eden \& Aviram 1993). While encouraging job seekers to take charge of their affairs is undoubtedly a good thing among external job seekers who would otherwise remain on the couch, increasing the internality of job seekers is not an unambiguously welfare-enhancing intervention given the effect internality has on reservation wages. Very internal job seekers may "make the perfect the enemy of the good" and hold out for excessively high wages. Moreover, determining which job seekers are too internal or too external in the context of job search would be nearly impossible. The only way to increase the expected utility of job seekers is to properly "calibrate" their beliefs about the efficacy of search. Many job seekers—especially young people with little experience looking for work—have no idea how much or how hard to search. They may rely on their general perceptions of how the world works-i.e., general locus of control and optimism-pessimism beliefs-when choosing how much effort to put into search. Providing job seekers with information about how the job market works and how much effort others exerted in job searches in similar occupations or industries can reduce their reliance on general beliefs when forming beliefs about the job market.

To this end, some subjects in our experiment participated in a partial information treatment in which they were provided with information concerning the experiences of prior subjects. Table 12 reports the coefficient estimates from our preferred specifications of the models of beliefs, reservation offers, and items completed in this partial information treatment. While the sample sizes 
are small, the coefficient estimates in columns 2 and 3 provide no evidence indicating that subjects' locus of control beliefs play a role in determining their reservation offer and effort choices when subjects have some information concerning the experiences of the other subjects. Counseling that provides young or inexperienced job seekers with information concerning the job search experiences of others may be a straightforward and effective way to eliminate behavioral biases that result from locus of control beliefs and increase the expected utility of job seekers.

Second, identifying job seekers at risk of becoming discouraged would help assistance programs target resources at these individuals. One might expect discouragement to be minimal in a two-hour experiment, but this proved not to be the case. We define "quitting" in any period to mean that either the subject completes no items or stopped coding before the end of the 90 -second coding window. ${ }^{7}$ Subjects exhibiting this behavior chose to exert less effort than other subjects and did so in an extreme fashion. We estimate a probit models of the probability of quitting in which a subject quits $\left(\right.$ Quit $\left._{i t}=1\right)$ whenever $Q u i t_{i t}^{*} \geq 0$ and $Q u i t_{i t}=0$ otherwise where $Q u i t_{i t}^{*}$ is the latent index

$$
\text { Quit }_{i t}^{*}=\delta_{1} \text { Locus }_{i}+X_{i} \delta_{2}+\delta_{3} t+\epsilon_{i t}
$$

Table 13 reports the estimated marginal effects in the limited information treatment (column 1) and the full information treatment (column 2). In both treatments, internality is negatively related to the probability of quitting, although the effect is not statistically significant in the full information treatment and roughly half the magnitude of the estimated marginal effect in the limited information treatment. In the limited information treatment, a one standard deviation increase in internality is associated with a reduction in the predicted probability of quitting in any period of 7.5 percentage

\footnotetext{
${ }^{7}$ As seen in figure 1, subjects could exit the coding task at any time by clicking a "Stop" button. Because a period only ended when all subjects still searching finished the coding task, quitting did not help subjects to reduce their time in the lab.
} 
points. Of the personality traits, only emotional stability has a comparable effect on the probability of quitting. The decision to quit appears to be closely related to locus of control beliefs - especially when subjects are uncertain about the return to their effort.

Our findings concerning discouragement complement those of Falk et al. (2006) who study search in an experiment in which the effectiveness of subjects' search depends on their type. Subjects are uncertain about their type - the real world analog of which would be their relative ability or desirability to potential employers - which they learn about through experience searching, which is costly. Unlucky initial search experiences lead some subjects to infer their type to be "lower" than it actually is and quit searching prematurely believing the costs to outweigh the expected benefits. Searchers become discouraged by dint of perfectly rational Bayesian updating. Our findings also suggest that discouragement can result from uncertainty about the return to search, but this uncertainty need not concern one's type. Instead, discouragement may be the result of a behavioral bias stemming from locus of control beliefs that inclines external searchers to believe search effort to be less effective than it actually is at the outset of their search episode. Unlucky search experiences can reinforce this bias and lead external searchers to give up.

That unlucky experiences might reinforce external beliefs leading to discouragement is not inconsistent or incompatible with the explanation offered by Falk et al. The difference between the two explanations, however, has important implications for programs attempting to prevent job seekers from becoming discouraged. Identifying job seekers who will be unlucky in the sense that conditional on their search effort and desirability to potential employers they will receive fewer offers than they could reasonably expect is a fool's errand. Identifying job seekers who are relatively external and hence most at risk of becoming discouraged, on the other hand, is relatively easy with a 
short questionnaire and could prove to be a viable approach to targeting resources at unemployed job seekers most in need of assistance-or simply encouragement.

\section{Discussion and Conclusion}

Success in labor markets depends on conventional human capital such as education, training, and cognitive ability, but it also depends on one's personality, social skills, patience, risk preferences, and other less easily measured but no less important "soft skills." Measures of many soft skills are available in longitudinal surveys, and economists have shown an increased willingness to explore their role in behavior (e.g., Borghans, ter Weel, \& Weinberg 2008). In many cases, however, economists have remained agnostic about what these measures of soft skills actually measure and how they influence behavior (e.g., Heckman, Stixrud, \& Urzua 2006). The laboratory affords economists the opportunity to identify what soft skills these survey instruments actually measure and how they influence behavior - and this is precisely the goal of this study regarding locus of control.

If locus of control affects beliefs about the efficacy of effort-as psychologists believe it does - then internal job seekers will set higher reservation wages and exert more effort looking for work. Consistent with these expectations, internality is positively related to reservation wages and search effort among unemployed job seekers in survey data. Alternative explanations for the correlation between locus of control and search behavior, however, cannot be ruled out using survey data. First, locus of control may be correlated with unobserved personal characteristics that influence the desirability of the job seeker as an employee. Second, the process of looking for work itself may require skills with which locus of control is correlated: internal individuals may simply be more effective searchers. Third, more internal workers may find search effort less bothersome. All three scenarios would imply that more internal job seekers would exert more effort looking for work and hold out for higher wages. 
Our experimental design allows us to determine whether these alternative explanations can explain the relationship between locus of control and search behavior. Subjects participate in two treatments: one in which the return to effort is uncertain and one in which the return to effort is common knowledge. In both treatments, the task by which subjects search is the same-meaning that a correlation between locus of control and unobserved skill or effort costs cannot explain a difference between treatments in the effects of locus of control. A clear treatment effect, however, emerges: more internal subjects exert more effort and hold out for higher offers than less internal subjects when the return to effort is uncertain, but there is no difference in behavior associated with internality when the return to effort is common knowledge. Internal individuals believe that their actions determine what happens to them. They search harder than less internal individuals because they believe this effort is more likely to lead to an offer, and because they expect offers to be more likely conditional on effort they hold out for higher offers.

Understanding how locus of control affects behavior in this abstract search setting has two benefits. First, economists can incorporate this understanding of how locus of control influences behavior into models of decision-making in broad range of contexts. Any decision requiring an individual to expend effort when the payoff to that effort is uncertain could be affected by locus of control beliefs. Our study provides guidance concerning how to model locus of control's effect on behavior in these settings and thereby derive testable predictions regarding such behavior. Second and more importantly, knowing how locus of control affects behavior can guide policy to help individuals overcome behavioral biases that hinder their employment prospects and reduce their welfare more generally. 


\section{References}

Andrisani, Paul J. 1977. "Internal-External Attitudes, Personal Initiative, and the Labor Market Experience of Black and White Men.” Journal of Human Resources, 12, 308-328.

Andrisani, Paul J. 1981. "Internal-External Attitudes, Sense of Efficacy, and Labor Market Experience: A Reply to Duncan and Morgan.” Journal of Human Resources, 658-666.

Baron, Juan D. and Deborah Cobb-Clark. 2010. "Are Young People's Educational Outcomes Linked to their Sense of Control?” IZA Discussion Paper 4907.

Borghans, Lex, Bas ter Weel, and Bruce A. Weinberg. 2008. "Interpersonal Styles and Labor Market Outcomes." Journal of Human Resources 43(4): 815-858.

Bowles, Samuel, Herbert Gintis, and Melissa Osborne. 2001. "Incentive-Enhancing Preferences: Personality, Behavior and Earnings." AEA Papers and Proceedings, 91, 155-158.

Braunstein, Yale M. and Andrew Schotter. 1981. "Economic Search: An Experimental Study." Economic Inquiry, 19, 1-25.

Braunstein, Yale M. and Andrew Schotter. 1982. "Labor Market Search: An Experimental Study." Economic Inquiry, 20, 133-144.

Brown, Meta, Christopher Flinn, and Andrew Schotter. 2011. "Real-Time Search in the Laboratory and the Market." American Economic Review, 101(2), 948-974

Caliendo, Marco, Deborah Cobb-Clark, and Arne Uhlendorff. 2010. "Locus of Control and Job Search Strategies.” IZA Discussion Paper no. 4750.

Coleman, Margo and Thomas DeLeire. 2003. "An Economic Model of Locus of Control and the Human Capital Investment Decision.” Journal of Human Resources, 38, 701-21.

Cox, James C. and Ronald L. Oaxaca. 1989. "Laboratory Experiments with a Finite Horizon JobSearch Model." Journal of Risk and Uncertainty, 2, 301-330.

Dextraze, Rhonda D. 1986. "The effects of a re-entry program on locus of control and self-regard." Master's Thesis, University of British Columbia.

Eden, Dov and Arie Aviram. 1993. "Self-efficacy training to speed reemployment: Helping people to help themselves." Journal of Applied Psychology, 78, 352-360.

Falk, Armin and Ernst Fehr. 2003. "Why labour market experiments?" Labour Economics, 10, 399406.

Falk, Armin, David Huffman and Uwe Sunde. 2006. "Do I have What it Takes? Equilibrium Search with Type Uncertainty and Non-participation.” IZA Discussion Paper No. 2531. 
Findley, Maureen J. and Harris M. Cooper. 1983. "Locus of control and academic achievement: A literature review." Journal of Personality and Social Psychology, 44(2), 419-427.

Goldberg, L. R. 1992. "The development of markers for the Big-Five factor structure." Psychological Assessment, 4, 26-42.

Goldsmith, Arthur, Jonathan Veum, and William Darity Jr. 1997. "The Impact of Psychological and Human Capital on Wages.” Economic Inquiry, 35, 815-829.

Heckman, James, Jora Stixrud, and Sergio Urzua. 2006. "The Effects of Cognitive and Noncognitive Abilities on Labor Market Outcomes and Social Behavior.” Journal of Labor Economics, 24, 411-482.

Holt, Charles A. and Susan K. Laury. 2002. "Risk Aversion and Incentive Effects." American Economic Review, 92(5), 1644-1655.

McGee, Andrew D. 2010. "How the Perception of Control Influences Unemployed Job Search." Working Paper.

Osborne-Groves, Melissa. 2005. "How important is your personality? Labor market returns to personality for women in the US and UK." Journal of Economic Psychology, 26, 827-841.

Piatek, Remi and Pia Pinger. 2010. "Maintaining (Locus of) Control? Assessing the Impact of Locus of Control on Education Decisions and Wages.” IZA Discussion Paper No. 5289.

Rosenberg, Morris. 1965. Society and the Adolescent Self-Image. Princeton: Princeton University Press.

Rotter, Julian B. 1966. Generalized Expectancies for Internal Versus External Control of Reinforcement. Psychological Monographs General and Applied, 80 (1, Whole No. 609).

Scheier, M. F., Carver, C. S., \& Bridges, M. W. 1994. "Distinguishing optimism from neuroticism (and trait anxiety, self-mastery, and self-esteem): A re-evaluation of the Life Orientation Test." Journal of Personality and Social Psychology, 67, 1063-1078.

Schweitzer, Stuart O. and Robert E. Smith. 1974. "The Persistence of the Discouraged Worker Effect." Industrial and Labor Relations Review, 27(2), 249-260. 
Figure 1a: Word-coding task screenshot for the limited information treatment

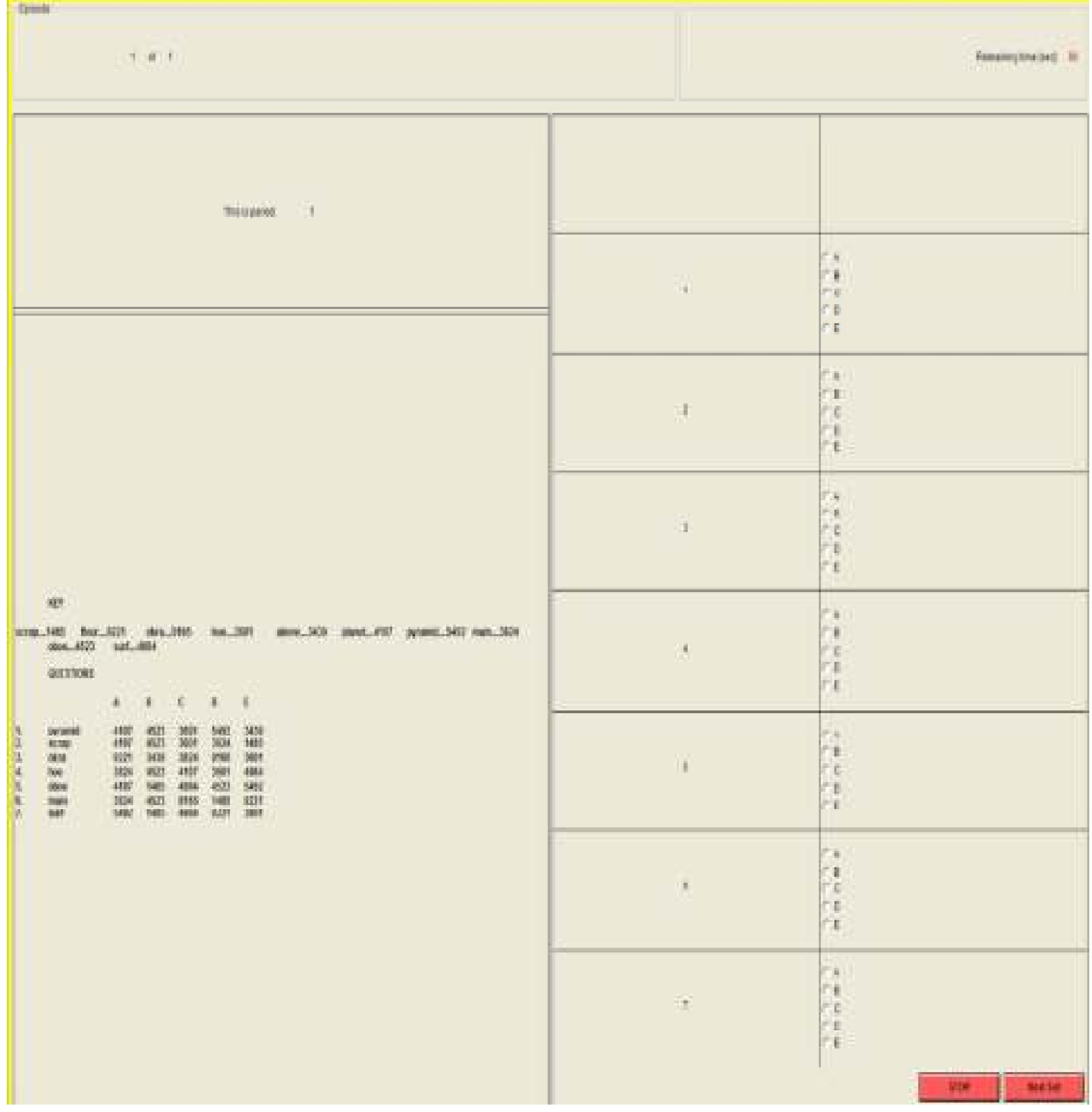


Figure 1b: Word-coding task screenshot for the full information treatment

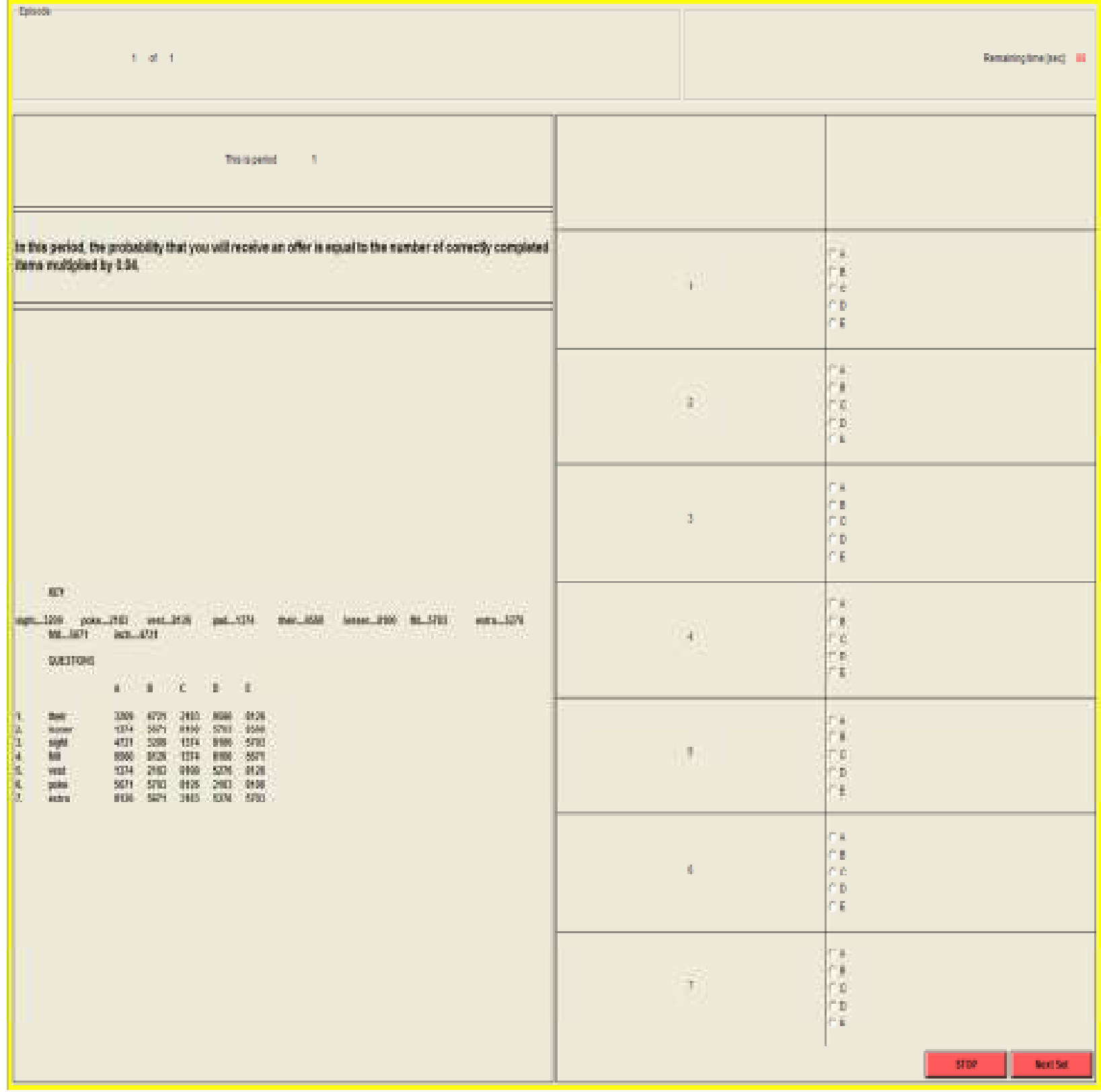


Figure 3: Partial information treatment information sheet

\begin{tabular}{|c|c|c|c|c|c|c|c|}
\hline Subiprt & $\begin{array}{l}\text { W if currectly } \\
\text { completed } \\
\text { itemi }\end{array}$ & $\begin{array}{c}\text { Receicued an } \\
\text { offer? }\end{array}$ & Amoust of offer & Subject: & $\begin{array}{l}4 \text { of correctly } \\
\text { esappleted } \\
\text { items }\end{array}$ & $\begin{array}{c}\text { Received an } \\
\text { offee? }\end{array}$ & $\begin{array}{l}\text { Aroount of } \\
\text { offes }\end{array}$ \\
\hline 1 & 7 & $Y=$ & 10 & BI & 14 & Ye & 10 \\
\hline 2 & 14 & $\mathrm{Xo}$ & $\mathrm{X} / \mathrm{A}$ & 32 & 14 & $Y=1$ & 40 \\
\hline 3 & 14 & Yo & $\mathrm{X} / \mathrm{A}$ & 33 & 7 & No & $\mathrm{X} / \mathrm{A}$ \\
\hline+ & 13 & $\mathrm{Xo}_{\mathrm{o}}$ & N/A & 34 & 14 & $\mathrm{~N}_{0}$ & $\mathrm{X} / \mathrm{A}$ \\
\hline 5 & $?$ & $X_{0}$ & $\mathrm{NA}$ & 33 & 21 & Yea & 5 \\
\hline 6 & 14 & $\mathrm{No}$ & $\mathrm{X} \subset \mathrm{A}$ & 35 & 6 & $Y_{t a}$ & 15 \\
\hline 7 & 21 & Yob & 5 & II & 13 & $\mathrm{~N}_{0}$ & $\mathrm{X} / \mathrm{A}$ \\
\hline 8 & 17 & $\bar{Y}=t$ & 35 & $\overline{33}$ & 13 & Yea & $\overline{5}$ \\
\hline 9 & 7 & No & $\mathrm{N} / \mathrm{A}$ & 39 & 14 & $\mathrm{Ye}_{\mathrm{a}}$ & is \\
\hline 10 & 14 & No & $X / A$ & 69 & 14 & Yea & 15 \\
\hline II & 2 & Yes & 5 & if & 2 & $\mathrm{~N}_{6}$ & $\mathrm{~N} / \mathrm{A}$ \\
\hline 12 & 13 & $Y_{* t}$ & 15 & 62 & 14 & Yea & 10 \\
\hline 113 & 14 & So & $\mathrm{N} / \mathrm{A}$ & 51 & 7 & No & N/A \\
\hline 14 & 18 & $\bar{Y}=4$ & 10 & 4 & 7 & Xo & $\operatorname{sit}$ \\
\hline 5 & 14 & Yes & 15 & t5 & 6 & $N_{0}$ & $\mathrm{~N} / \mathrm{A}$ \\
\hline Iא & 7 & Yea & 5 & 65 & 15 & Ya & 40 \\
\hline 17 & 14 & $Y=$ & 10 & 47 & 14 & $Y=$ & 10 \\
\hline II & 13 & Yes & 5 & ti & 7 & $v_{6}$ & $\mathrm{~K} / \mathrm{A}$ \\
\hline 79 & 14 & Xo & $\mathrm{X} / \mathrm{A}$ & w & $\theta$ & No & रात \\
\hline 20 & 7 & $Y=s$ & 10 & (5) & 21 & $Y_{e}$ & 10 \\
\hline 21 & 14 & $\mathrm{No}_{0}$ & $\mathrm{~N} / \mathrm{A}$ & 51 & 11 & Yea & 10 \\
\hline 22 & 14 & No & N/A & $\overrightarrow{3 z}$ & 13 & Yes & 3 \\
\hline 23 & 7 & No & $\mathrm{N} / \mathrm{A}$ & 53 & 7 & Yea & b \\
\hline 24 & 13 & $Y e s$ & 15 & 54 & 7 & $\mathrm{x}_{0}$ & $\mathrm{~N} / \mathrm{A}$ \\
\hline 2 & 7 & No & N $/ A$ & क) & 7 & No & X/A \\
\hline 86 & 14 & Xe & N/A & 86 & 7 & $\mathrm{~N}_{0}$ & $\mathrm{X} / \mathrm{A}$ \\
\hline है & 0 & Ye & $\mathrm{N} / \mathrm{d}$ & 53 & 7 & $\mathrm{~K}_{0}$ & $\mathrm{X} / \mathrm{A}$ \\
\hline II & 7 & Yes & IVI & कs & 0 & No & N/A \\
\hline 29 & 14 & Se & N/A & 89 & 7 & $\mathrm{~N}_{0}$ & $\mathrm{X} / \mathrm{A}$ \\
\hline प्र & 14 & $\mathrm{Xo}_{0}$ & $\mathrm{~N} / \mathrm{A}$ & 60 & 12 & Yea & 13 \\
\hline
\end{tabular}


Table 1: Offer distribution

\begin{tabular}{ll}
\hline Offer & Probability \\
\hline 5 & .25 \\
10 & .25 \\
15 & .25 \\
20 & .10 \\
35 & .05 \\
40 & .05 \\
45 & .05 \\
\hline \hline
\end{tabular}


Table 2: Summary of experimental sessions

\begin{tabular}{|c|c|c|c|c|c|c|c|}
\hline \multirow[b]{2}{*}{$\begin{array}{l}\text { Session } \\
\text { Type }\end{array}$} & \multicolumn{7}{|c|}{ Subject-period observations by treatment } \\
\hline & $\begin{array}{l}\text { Number } \\
\text { of } \\
\text { subjects }\end{array}$ & $\begin{array}{l}\text { Limited } \\
\text { information, } \\
\text { real-effort } \\
\text { treatment }\end{array}$ & $\begin{array}{l}\text { Full } \\
\text { information, } \\
\text { real-effort } \\
\text { treatment }\end{array}$ & $\begin{array}{l}\text { Partial } \\
\text { information, } \\
\text { real-effort } \\
\text { treatment }\end{array}$ & $\begin{array}{l}\text { Limited } \\
\text { information, } \\
\text { pseudo-effort } \\
\text { treatment }\end{array}$ & $\begin{array}{l}\text { Full } \\
\text { information, } \\
\text { pseudo-effort } \\
\text { treatment }\end{array}$ & $\begin{array}{l}\text { Average } \\
\text { Earnings }\end{array}$ \\
\hline Baseline & 77 & 723 & 641 & 0 & 0 & 0 & $\begin{array}{l}\$ 20.10 \\
(2.29)\end{array}$ \\
\hline $\begin{array}{l}\text { Partial } \\
\text { Information }\end{array}$ & 36 & 304 & 342 & 326 & 0 & 0 & $\begin{array}{l}\$ 23.50 \\
(3.49)\end{array}$ \\
\hline $\begin{array}{l}\text { Pseudo } \\
\text { Effort }\end{array}$ & 42 & 383 & 304 & 0 & 425 & 380 & $\begin{array}{l}\$ 23.98 \\
(5.02)\end{array}$ \\
\hline Totals & 155 & 1410 & 1287 & 326 & 425 & 380 & $\begin{array}{l}\$ 21.88 \\
(4.00)\end{array}$ \\
\hline
\end{tabular}

Note: Standard deviations in parentheses. 
Table 3: Means and standard deviations of reservation offers and items completed by period and treatment

\begin{tabular}{|c|c|c|c|c|c|c|}
\hline \multirow[b]{2}{*}{ Period } & \multicolumn{2}{|c|}{ Limited information } & \multicolumn{2}{|c|}{ Full information } & \multicolumn{2}{|c|}{ Theoretical prediction } \\
\hline & $\begin{array}{l}\text { Reservation } \\
\text { offer }\end{array}$ & $\begin{array}{l}\text { Items } \\
\text { completed }\end{array}$ & $\begin{array}{l}\text { Reservation } \\
\text { offer }\end{array}$ & $\begin{array}{l}\text { Items } \\
\text { completed }\end{array}$ & $\begin{array}{l}\text { Reservation } \\
\text { offer }\end{array}$ & $\begin{array}{l}\text { Items } \\
\text { completed }\end{array}$ \\
\hline 1 & $\begin{array}{l}32.10 \\
(12.63) \\
\mathrm{N}=155\end{array}$ & $\begin{array}{l}6.85 \\
(3.60)\end{array}$ & $\begin{array}{l}31.43 \\
(10.68) \\
N=155\end{array}$ & $\begin{array}{l}12.12 \\
(3.86)\end{array}$ & 35 & 12 \\
\hline 2 & $\begin{array}{l}30.17 \\
(11.37) \\
\mathrm{N}=144\end{array}$ & $\begin{array}{l}10.03 \\
(4.09)\end{array}$ & $\begin{array}{l}31.89 \\
(10.75) \\
N=143\end{array}$ & $\begin{array}{l}13.08 \\
(3.65)\end{array}$ & 35 & 11 \\
\hline 3 & $\begin{array}{l}30.31 \\
(10.13) \\
\mathrm{N}=136\end{array}$ & $\begin{array}{l}10.63 \\
(4.44)\end{array}$ & $\begin{array}{l}31.56 \\
(9.97) \\
\mathrm{N}=126\end{array}$ & $\begin{array}{l}13.55 \\
(3.61)\end{array}$ & 20 & 11 \\
\hline 4 & $\begin{array}{l}29.14 \\
(9.24) \\
\mathrm{N}=125\end{array}$ & $\begin{array}{l}10.83 \\
(4.48)\end{array}$ & $\begin{array}{l}29.88 \\
(10.60) \\
N=112\end{array}$ & $\begin{array}{l}13.73 \\
(3.68)\end{array}$ & 20 & 11 \\
\hline 5 & $\begin{array}{l}28.03 \\
(10.23) \\
\mathrm{N}=111\end{array}$ & $\begin{array}{l}11.38 \\
(4.29)\end{array}$ & $\begin{array}{l}28.59 \\
(9.90) \\
\mathrm{N}=102\end{array}$ & $\begin{array}{l}12.63 \\
(3.61)\end{array}$ & 20 & 11 \\
\hline 6 & $\begin{array}{l}27.55 \\
(9.94) \\
N=100\end{array}$ & $\begin{array}{l}10.94 \\
(4.15)\end{array}$ & $\begin{array}{l}26.97 \\
(10.75) \\
\mathrm{N}=93\end{array}$ & $\begin{array}{l}12.90 \\
(3.89)\end{array}$ & 20 & 10 \\
\hline 7 & $\begin{array}{l}27.31 \\
(9.80) \\
N=88\end{array}$ & $\begin{array}{l}10.88 \\
(4.47)\end{array}$ & $\begin{array}{l}28.16 \\
(10.88) \\
N=79\end{array}$ & $\begin{array}{l}12.12 \\
(3.68)\end{array}$ & 20 & 10 \\
\hline 8 & $\begin{array}{l}25.95 \\
(10.22) \\
N=79\end{array}$ & $\begin{array}{l}9.85 \\
(4.52)\end{array}$ & $\begin{array}{l}28.14 \\
(10.34) \\
N=72\end{array}$ & $\begin{array}{l}13.89 \\
(4.02)\end{array}$ & 20 & 9 \\
\hline 9 & $\begin{array}{l}25.39 \\
(9.99) \\
\mathrm{N}=72\end{array}$ & $\begin{array}{l}10.24 \\
(4.69)\end{array}$ & $\begin{array}{l}27.30 \\
(11.21) \\
N=63\end{array}$ & $\begin{array}{l}13.84 \\
(5.69)\end{array}$ & 20 & 9 \\
\hline 10 & $\begin{array}{l}25.74 \\
(9.31) \\
\mathrm{N}=65\end{array}$ & $\begin{array}{l}10.49 \\
(4.82)\end{array}$ & $\begin{array}{l}25.83 \\
(10.38) \\
N=60\end{array}$ & $\begin{array}{l}12.92 \\
(3.61)\end{array}$ & 20 & 9 \\
\hline 11 & $\begin{array}{l}24.93 \\
(8.86) \\
\mathrm{N}=60\end{array}$ & $\begin{array}{l}10.52 \\
(5.25)\end{array}$ & $\begin{array}{l}25.56 \\
(9.60) \\
\mathrm{N}=54\end{array}$ & $\begin{array}{l}11.96 \\
(4.02)\end{array}$ & 20 & 8 \\
\hline
\end{tabular}

Continued 
Table 3 continued

\begin{tabular}{|c|c|c|c|c|c|c|}
\hline \multirow[b]{2}{*}{ Period } & \multicolumn{2}{|c|}{ Limited information } & \multicolumn{2}{|c|}{ Full information } & \multicolumn{2}{|c|}{ Theoretical prediction } \\
\hline & $\begin{array}{l}\text { Reservation } \\
\text { offer }\end{array}$ & $\begin{array}{l}\text { Items } \\
\text { completed }\end{array}$ & $\begin{array}{l}\text { Reservation } \\
\text { offer }\end{array}$ & $\begin{array}{l}\text { Items } \\
\text { completed }\end{array}$ & $\begin{array}{l}\text { Reservation } \\
\text { offer }\end{array}$ & $\begin{array}{l}\text { Items } \\
\text { completed }\end{array}$ \\
\hline 12 & $\begin{array}{l}22.87 \\
(9.25) \\
\mathrm{N}=54\end{array}$ & $\begin{array}{l}10.43 \\
(5.09)\end{array}$ & $\begin{array}{l}24.89 \\
(10.77) \\
N=46\end{array}$ & $\begin{array}{l}13.52 \\
(5.03)\end{array}$ & 20 & 7 \\
\hline 13 & $\begin{array}{l}24.37 \\
(9.96) \\
\mathrm{N}=46\end{array}$ & $\begin{array}{l}9.96 \\
(5.54)\end{array}$ & $\begin{array}{l}23.57 \\
(9.89) \\
\mathrm{N}=42\end{array}$ & $\begin{array}{l}14.86 \\
(4.38)\end{array}$ & 20 & 7 \\
\hline 14 & $\begin{array}{l}21.47 \\
(8.98) \\
\mathrm{N}=38\end{array}$ & $\begin{array}{l}9.16 \\
(5.49)\end{array}$ & $\begin{array}{l}25.59 \\
(9.83) \\
\mathrm{N}=10\end{array}$ & $\begin{array}{l}12.88 \\
(4.54)\end{array}$ & 15 & 6 \\
\hline 15 & $\begin{array}{l}21.39 \\
(9.10) \\
\mathrm{N}=31\end{array}$ & $\begin{array}{l}8.06 \\
(5.89)\end{array}$ & $\begin{array}{l}20.19 \\
(9.00) \\
\mathrm{N}=26\end{array}$ & $\begin{array}{l}13.15 \\
(4.10)\end{array}$ & 15 & 6 \\
\hline 16 & $\begin{array}{l}21.77 \\
(9.56) \\
\mathrm{N}=26\end{array}$ & $\begin{array}{l}9.12 \\
(6.22)\end{array}$ & $\begin{array}{l}21.82 \\
(8.39) \\
\mathrm{N}=22\end{array}$ & $\begin{array}{l}12.50 \\
(3.94)\end{array}$ & 15 & 5 \\
\hline 17 & $\begin{array}{l}20.70 \\
(8.27) \\
\mathrm{N}=23\end{array}$ & $\begin{array}{l}8.57 \\
(5.56)\end{array}$ & $\begin{array}{l}20.60 \\
(8.73) \\
\mathrm{N}=20\end{array}$ & $\begin{array}{l}11.00 \\
(5.79)\end{array}$ & 15 & 5 \\
\hline 18 & $\begin{array}{l}21.00 \\
(8.57) \\
\mathrm{N}=21\end{array}$ & $\begin{array}{l}7.19 \\
(6.42)\end{array}$ & $\begin{array}{l}20.88 \\
(10.04) \\
N=17\end{array}$ & $\begin{array}{l}11.29 \\
(5.59)\end{array}$ & 15 & 4 \\
\hline 19 & $\begin{array}{l}18.47 \\
(6.65) \\
\mathrm{N}=19\end{array}$ & $\begin{array}{l}8.32 \\
(6.56)\end{array}$ & $\begin{array}{l}22.50 \\
(12.34) \\
\mathrm{N}=12\end{array}$ & $\begin{array}{l}11.25 \\
(5.69)\end{array}$ & 10 & 3 \\
\hline 20 & $\begin{array}{l}22.94 \\
(11.19) \\
\mathrm{N}=17\end{array}$ & $\begin{array}{l}6.00 \\
(6.28)\end{array}$ & $\begin{array}{l}18.33 \\
(12.75) \\
\mathrm{N}=9\end{array}$ & $\begin{array}{l}9.22 \\
(5.93)\end{array}$ & 5 & 3 \\
\hline
\end{tabular}

Note: Standard deviations in parentheses. 
Table 4: Summary statistics

\begin{tabular}{lllll}
\hline Variable & Mean & Standard deviation & Minimum & Maximum \\
\hline Locus of control & 12.03 & 2.43 & 6 & 16 \\
HRS risk preference measure & 2.52 & 1.15 & 1 & 4 \\
GSOEP risk preference measure & 3.81 & 2.02 & 0 & 8 \\
HL risk preference measure & 5.51 & 1.53 & 0 & 10 \\
Optimism-pessimism score & 16.81 & 4.46 & 0 & 24 \\
Self-esteem score & 32.61 & 4.59 & 11 & 40 \\
Big One score (Extroversion) & 33.86 & 8.28 & 13 & 40 \\
Big Two score (Agreeableness) & 39.83 & 5.49 & 16 & 49 \\
Big Three score (Conscientiousness) & 36.40 & 6.11 & 17 & 48 \\
Big Four score (Emotional stability) & 32.79 & 7.44 & 23 & 790 \\
Big Five score (Intellect) & 38.03 & 5.35 & 390 & 800 \\
SAT Verbal score & 601.03 & 102.80 & 560 & 750 \\
(N=39) & & & & \\
SAT Math score & 727.66 & 63.29 & 410 & 35 \\
(N=47) & & & & \\
SAT Writing score & 609.38 & 83.12 & & \\
(N=32) & & & & \\
ACT score & 27.68 & 3.42 & & \\
(N=96) & & & & \\
White & 0.64 & & & \\
Black & 0.10 & & & \\
Other race & 0.26 & &
\end{tabular}

Note: Sample size equals 155 unless otherwise noted. Locus of control is increasing in internality. The risk preference measures are increasing in risk aversion. Optimism-pessimism is increasing in optimism (decreasing in pessimism). Self-esteem is increasing in an individual's degree of selfapproval. Big One is increasing in extroversion. Big Two is increasing in agreeableness. Big Three is increasing in conscientiousness. Big Four is increasing in emotional stability. Big Five is increasing in one's intellectual orientation or imaginativeness. 
Table 5: Pairwise correlation coefficients for personality measures

\begin{tabular}{|c|c|c|c|c|c|c|c|c|c|c|c|}
\hline & LOC & HRS & GSR & HLR & OPP & EST & BG1 & BG2 & BG3 & BG4 & BG5 \\
\hline $\begin{array}{l}\text { Locus of control } \\
\text { (LOC) }\end{array}$ & 1.00 & & & & & & & & & & \\
\hline HRS risk (HRS) & $\begin{array}{l}0.10 \\
(0.21)\end{array}$ & 1.00 & & & & & & & & & \\
\hline GSOEP risk (GSR) & $\begin{array}{l}-0.08 \\
(0.33)\end{array}$ & $\begin{array}{l}-0.01 \\
(0.89)\end{array}$ & 1.00 & & & & & & & & \\
\hline H-L risk (HLR) & $\begin{array}{c}0.01 \\
(0.86)\end{array}$ & $\begin{array}{l}0.20 \\
(0.01)\end{array}$ & $\begin{array}{c}0.26 \\
(0.00)\end{array}$ & 1.00 & & & & & & & \\
\hline $\begin{array}{l}\text { Optimism- } \\
\text { pessimism (OPP) }\end{array}$ & $\begin{array}{c}0.34 \\
(0.00)\end{array}$ & $\begin{array}{l}0.07 \\
(0.41)\end{array}$ & $\begin{array}{l}-0.11 \\
(0.19)\end{array}$ & $\begin{array}{c}0.04 \\
(0.65)\end{array}$ & 1.00 & & & & & & \\
\hline Self-esteem (EST) & $\begin{array}{l}0.38 \\
(0.00)\end{array}$ & $\begin{array}{l}0.03 \\
(0.70)\end{array}$ & $\begin{array}{l}-0.17 \\
(0.04)\end{array}$ & $\begin{array}{c}-0.01 \\
(0.86)\end{array}$ & $\begin{array}{l}0.57 \\
(0.00)\end{array}$ & 1.00 & & & & & \\
\hline Big One (BG1) & 0.33 & 0.17 & -0.34 & 0.03 & 0.24 & 0.27 & 1.00 & & & & \\
\hline Extroversion & $(0.00)$ & $(0.04)$ & $(0.00)$ & $(0.75)$ & $(0.00)$ & $(0.00)$ & & & & & \\
\hline Big Two (BG2) & 0.15 & 0.01 & -0.04 & 0.13 & 0.14 & 0.13 & 0.29 & 1.00 & & & \\
\hline Agreeableness & $(0.07)$ & $(0.93)$ & $(0.66)$ & $(0.10)$ & $(0.07)$ & $(0.11)$ & $(0.00)$ & & & & \\
\hline Big Three (BG3) & 0.30 & -0.05 & 0.14 & 0.03 & 0.19 & 0.28 & 0.02 & 0.16 & 1.00 & & \\
\hline Conscientiousness & $(0.00)$ & $(0.51)$ & $(0.09)$ & $(0.74)$ & $(0.02)$ & $(0.00)$ & $(0.78)$ & $(0.04)$ & & & \\
\hline Big Four (BG4) & 0.18 & -0.04 & -0.11 & -0.14 & 0.34 & 0.47 & 0.02 & -0.10 & -0.01 & 1.00 & \\
\hline Emotional stability & $(0.03)$ & $(0.64)$ & $(0.16)$ & $(0.09)$ & $(0.00)$ & $(0.00)$ & $(0.80)$ & $(0.20)$ & $(0.95)$ & & \\
\hline Big Five (BG5) & 0.11 & 0.09 & -0.25 & 0.03 & 0.09 & 0.12 & 0.28 & 0.19 & -0.02 & 0.01 & 1.00 \\
\hline Intellect & $(0.17)$ & $(0.26)$ & $(0.00)$ & $(0.68)$ & $(0.27)$ & $(0.14)$ & $(0.00)$ & $(0.02)$ & $(0.85)$ & $(0.85)$ & \\
\hline
\end{tabular}

Note: Significance levels in parentheses. Locus of control (LOC) is increasing in internality. The risk preference measures (HRS, GSR, and HLR) are increasing in risk aversion. Optimism-pessimism (OPP) is increasing in optimism (decreasing in pessimism). Self-esteem (EST) is increasing in an individual's degree of self-approval. Big One (BG1) is increasing in extroversion. Big Two (BG2) is increasing in agreeableness. Big Three (BG3) is increasing in conscientiousness. Big Four (BG4) is increasing in emotional stability. Big Five (BG5) is increasing in one's intellectual orientation or imaginativeness. 
Table 6: Coefficient estimates for the models of beliefs about the probability of receiving an offer in the limited information treatment.

\begin{tabular}{|c|c|c|c|}
\hline \multirow[b]{2}{*}{ Variable } & \multicolumn{3}{|c|}{ Coefficients } \\
\hline & (1) & (2) & (3) \\
\hline Correctly completed items & $\begin{array}{l}1.358^{* * *} \\
(0.379)\end{array}$ & $\begin{array}{c}0.890 \\
(0.245)\end{array}$ & \\
\hline Beliefs in period $t-1$ & & $\begin{array}{l}0.577 * * * \\
(0.049)\end{array}$ & \\
\hline Locus of control & & & $\begin{array}{l}-0.149 \\
(2.219)\end{array}$ \\
\hline Risk preferences & & & $\begin{array}{l}-2.872 \\
(1.906)\end{array}$ \\
\hline Optimism-pessimism & & & $\begin{array}{l}5.197 * * \\
(2.576)\end{array}$ \\
\hline Self-esteem & & & $\begin{array}{l}-3.386 \\
(2.642)\end{array}$ \\
\hline Big One & & & $-5.553 * *$ \\
\hline (Extroversion) & & & $(2.197)$ \\
\hline Big Two & & & 1.172 \\
\hline (Agreeableness) & & & $(2.087)$ \\
\hline Big Three & & & $-6.121 * * *$ \\
\hline (Conscientiousness) & & & $(2.276)$ \\
\hline Big Four & & & -0.770 \\
\hline (Emotional Stability) & & & (2.139) \\
\hline Big Five & & & -0.228 \\
\hline (Intellect) & & & $(2.429)$ \\
\hline Search cost decile & & & $\begin{array}{l}-0.676 \\
(0.611)\end{array}$ \\
\hline Period & $\begin{array}{l}-0.524^{*} \\
(0.287)\end{array}$ & & $\begin{array}{l}-0.607 * * \\
(0.265)\end{array}$ \\
\hline Constant & $\begin{array}{l}41.329^{* * * *} \\
(4.032)\end{array}$ & $\begin{array}{l}11.630^{* * *} \\
(2.733)\end{array}$ & $\begin{array}{l}58.134 * * * \\
(3.555)\end{array}$ \\
\hline $\mathrm{R}^{2}$ & 0.055 & 0.372 & 0.116 \\
\hline Subject-period observations & 1410 & 1255 & 1410 \\
\hline
\end{tabular}

Note: Standard errors in parentheses are clustered at the subject-level. The models are estimated by ordinary least squares. Risk preferences are measured using the lottery question from the HRS. *** - significant at $1 \% \quad * *$ - significant at $5 \% \quad * \quad$ - significant at $10 \%$ 
Table 7: Coefficient estimates for the models of reservation offers

\begin{tabular}{|c|c|c|c|c|c|c|c|}
\hline \multirow[b]{3}{*}{ Variable } & \multicolumn{7}{|c|}{ Coefficients } \\
\hline & \multicolumn{3}{|c|}{ Limited information } & \multirow[b]{2}{*}{ (4) } & \multicolumn{2}{|c|}{ Full Information } & \multirow[b]{2}{*}{ (7) } \\
\hline & (1) & (2) & (3) & & (5) & (6) & \\
\hline Beliefs in period $t$ & $\begin{array}{l}0.047^{* * *} \\
(0.016)\end{array}$ & & & & & & \\
\hline $\begin{array}{l}\text { Correctly } \\
\text { completed items }\end{array}$ & & $\begin{array}{l}0.108 * * \\
(0.050)\end{array}$ & & & $\begin{array}{l}0.167 * * \\
(0.075)\end{array}$ & & \\
\hline Locus of control & & & $\begin{array}{l}1.156^{*} \\
(0.593)\end{array}$ & $\begin{array}{l}0.049 * * \\
(0.023)\end{array}$ & & $\begin{array}{l}-0.192 \\
(0.708)\end{array}$ & $\begin{array}{l}0.008 \\
(0.028)\end{array}$ \\
\hline Risk preferences & & & $\begin{array}{l}-1.767 * * * \\
(0.563)\end{array}$ & $\begin{array}{l}-0.065 * * * \\
(0.025)\end{array}$ & & $\begin{array}{l}-0.761 \\
(0.728)\end{array}$ & $\begin{array}{l}-0.016 \\
(0.033)\end{array}$ \\
\hline $\begin{array}{l}\text { Optimism- } \\
\text { pessimism }\end{array}$ & & & $\begin{array}{l}1.086 \\
(0.679)\end{array}$ & $\begin{array}{l}0.036 \\
(0.027)\end{array}$ & & $\begin{array}{l}1.225 \\
(0.897)\end{array}$ & $\begin{array}{l}0.021 \\
(0.034)\end{array}$ \\
\hline Self-esteem & & & $\begin{array}{l}-0.663 \\
(0.848)\end{array}$ & $\begin{array}{l}-0.021 \\
(0.036)\end{array}$ & & $\begin{array}{l}-0.551 \\
(1.102)\end{array}$ & $\begin{array}{l}-0.015 \\
(0.050)\end{array}$ \\
\hline $\begin{array}{l}\text { Big One } \\
\text { (Extroversion) }\end{array}$ & & & $\begin{array}{l}-0.934 \\
(0.743)\end{array}$ & $\begin{array}{l}-0.039 \\
(0.029)\end{array}$ & & $\begin{array}{l}-0.121 \\
(0.876)\end{array}$ & $\begin{array}{l}0.008 \\
(0.035)\end{array}$ \\
\hline Big Two & & & 0.723 & 0.036 & & $-2.172 * *$ & $-0.082 *$ \\
\hline (Agreeableness) & & & $(0.719)$ & $(0.032)$ & & $(0.908)$ & $(0.044)$ \\
\hline Big Three & & & -0.631 & -0.032 & & -0.602 & -0.022 \\
\hline (Conscientiousness) & & & $(0.639)$ & $(0.024)$ & & $(0.790)$ & $(0.033)$ \\
\hline Big Four & & & -0.084 & 0.005 & & -0.666 & -0.019 \\
\hline (Emot. Stability) & & & $(0.594)$ & $(0.023)$ & & $(0.893)$ & $(0.042)$ \\
\hline Big Five & & & $1.468 * *$ & $0.076^{* *}$ & & 0.124 & 0.003 \\
\hline (Intellect) & & & $(0.606)$ & $(0.031)$ & & $(0.651)$ & $(0.027)$ \\
\hline Search cost decile & & & $\begin{array}{l}-0.101 \\
(0.214)\end{array}$ & $\begin{array}{l}-0.002 \\
(0.009)\end{array}$ & & $\begin{array}{l}-0.532 * \\
(0.286)\end{array}$ & $\begin{array}{l}-0.014 \\
(0.013)\end{array}$ \\
\hline Period & $\begin{array}{l}-0.630^{* * * *} \\
(0.084)\end{array}$ & $\begin{array}{l}-0.640 * * * \\
(0.083)\end{array}$ & $\begin{array}{l}-0.640 * * * \\
(0.078)\end{array}$ & $\begin{array}{l}-0.025 * * * \\
(0.003)\end{array}$ & $\begin{array}{l}-0.647 * * * \\
(0.104)\end{array}$ & $\begin{array}{l}-0.669^{* * * *} \\
(0.101)\end{array}$ & $\begin{array}{l}-0.023 * * * \\
(0.004)\end{array}$ \\
\hline Constant & $\begin{array}{l}29.258^{* * * *} \\
(1.247)\end{array}$ & $\begin{array}{l}30.355^{* * *} \\
(1.115)\end{array}$ & $\begin{array}{l}32.097^{* * *} \\
(1.202)\end{array}$ & $\begin{array}{l}3.408^{* * *} \\
(0.053)\end{array}$ & $\begin{array}{l}29.739^{* * *} \\
(1.474)\end{array}$ & $\begin{array}{l}34.953^{* * *} \\
(1.558)\end{array}$ & $\begin{array}{l}3.480 * * * \\
(0.065)\end{array}$ \\
\hline $\begin{array}{l}\text { Dependent } \\
\text { variable: } \log \\
\text { reservation offer }\end{array}$ & No & No & No & Yes & No & No & Yes \\
\hline $\mathrm{R}^{2}$ & 0.110 & 0.102 & 0.160 & 0.149 & 0.109 & 0.147 & 0.095 \\
\hline $\begin{array}{l}\text { Subject-period } \\
\text { observations }\end{array}$ & 1410 & 1410 & 1410 & 1,401 & 1287 & 1287 & 1,273 \\
\hline
\end{tabular}

Note: Standard errors in parentheses are clustered at the subject-level. The models are estimated by ordinary least squares. Risk preferences are measured using the lottery question from the HRS. $* * *$ - significant at $1 \%$ * $\quad *$ - significant at $5 \% \quad * \quad$ - significant at $10 \%$ 


\begin{tabular}{|c|c|c|}
\hline Variable & Limited information & Full information \\
\hline \multicolumn{3}{|l|}{ Beliefs in $t-1$} \\
\hline Locus of control & $\begin{array}{l}0.940 * * \\
(0.379)\end{array}$ & $\begin{array}{l}-0.294 \\
(0.371)\end{array}$ \\
\hline Risk preferences & $\begin{array}{l}-0.556 \\
(0.352)\end{array}$ & $\begin{array}{l}-0.113 \\
(0.346)\end{array}$ \\
\hline Optimism-pessimism & $\begin{array}{c}0.207 \\
(0.400)\end{array}$ & $\begin{array}{c}0.297 \\
(0.372)\end{array}$ \\
\hline Self-esteem & $\begin{array}{l}-0.334 \\
(0.463)\end{array}$ & $\begin{array}{c}0.070 \\
(0.415)\end{array}$ \\
\hline Big One & -0.490 & $-0.750 * *$ \\
\hline (Extroversion) & $(0.322)$ & $(0.370)$ \\
\hline Big Two & $0.687 * *$ & 0.093 \\
\hline (Agreeableness) & $(0.297)$ & $(0.310)$ \\
\hline Big Three & -0.499 & -0.409 \\
\hline (Conscientiousness) & $(0.323)$ & $(0.315)$ \\
\hline Big Four & 0.206 & -0.033 \\
\hline (Emotional Stability) & $(0.379)$ & $(0.292)$ \\
\hline Big Five & -0.356 & -0.333 \\
\hline (Intellect) & $(0.359)$ & $(0.273)$ \\
\hline \multirow[t]{2}{*}{ Search cost decile } & -0.139 & -0.078 \\
\hline & $(0.114)$ & $(0.118)$ \\
\hline \multirow[t]{2}{*}{ Period } & -0.005 & -0.027 \\
\hline & $(0.055)$ & $(0.046)$ \\
\hline \multirow[t]{2}{*}{ Constant } & $10.570 * * *$ & $13.477 * * *$ \\
\hline & $(0.658)$ & $(0.629)$ \\
\hline $\mathrm{R}^{2}$ & 0.074 & 0.057 \\
\hline Subject-period observations & 1410 & 1287 \\
\hline
\end{tabular}

Note: Standard errors in parentheses are clustered at the subject-level. The models are estimated by ordinary least squares. Risk preferences are measured using the lottery question from the HRS. $* * *$ - significant at $1 \% \quad * *-$ significant at $5 \% \quad * \quad$ - significant at $10 \%$ 
Table 9: Estimated marginal effects in pseudo-effort treatment

\begin{tabular}{|c|c|c|c|c|c|}
\hline \multirow[b]{3}{*}{ Variable } & \multicolumn{5}{|c|}{ Dependent variables } \\
\hline & \multirow[b]{2}{*}{ Beliefs } & \multicolumn{2}{|c|}{ Limited information treatment } & \multicolumn{2}{|c|}{ Full information treatment } \\
\hline & & $\begin{array}{l}\text { Reservation } \\
\text { offers }\end{array}$ & $\begin{array}{l}\text { Correctly } \\
\text { completed items }\end{array}$ & $\begin{array}{l}\text { Reservation } \\
\text { offers }\end{array}$ & $\begin{array}{l}\text { Correctly } \\
\text { completed items }\end{array}$ \\
\hline \multirow[t]{2}{*}{ Locus of control } & 0.291 & 3.369 & -0.509 & 0.196 & -0.718 \\
\hline & $(1.948)$ & $(2.882)$ & $(0.448)$ & $(1.284)$ & $(0.605)$ \\
\hline \multirow[t]{2}{*}{ Risk preferences } & 0.481 & -0.676 & 0.091 & $3.830 * *$ & 0.547 \\
\hline & $(2.122)$ & $(2.813)$ & $(0.783)$ & $(1.539)$ & $(0.698)$ \\
\hline \multirow[t]{2}{*}{ Optimism-pessimism } & -0.783 & 3.165 & 0.636 & 1.513 & $-2.060 * * *$ \\
\hline & $(2.683)$ & $(3.128)$ & $(0.725)$ & $(1.160)$ & $(0.633)$ \\
\hline \multirow{2}{*}{ Self-esteem } & $-7.903 * *$ & $-8.217 *$ & $-2.988 * * *$ & $-3.242 *$ & -0.252 \\
\hline & $(3.409)$ & $(4.529)$ & $(0.737)$ & $(1.628)$ & $(0.652)$ \\
\hline Big One & -5.781 & -2.464 & 0.014 & $2.231^{*}$ & -0.630 \\
\hline (Extroversion) & $(3.865)$ & $(3.930)$ & $(0.604)$ & $(1.221)$ & $(0.506)$ \\
\hline Big Two & 2.646 & -1.237 & -0.592 & -0.124 & $1.529 * *$ \\
\hline (Agreeableness) & $(2.411)$ & $(1.783)$ & $(0.550)$ & $(1.513)$ & $(0.673)$ \\
\hline Big Three & $-7.701 * *$ & -1.162 & 0.582 & -1.345 & -1.101 \\
\hline (Conscientiousness) & $(3.722)$ & $(2.627)$ & $(0.926)$ & $(1.334)$ & $(0.706)$ \\
\hline Big Four & 2.807 & 4.920 & 1.020 & 0.319 & $1.522 * *$ \\
\hline (Emotional Stability) & $(3.130)$ & $(3.764)$ & $(0.783)$ & $(1.477)$ & $(0.600)$ \\
\hline Big Five & 2.606 & $5.557 * *$ & 0.228 & $2.061^{*}$ & -0.206 \\
\hline (Intellect) & $(2.827)$ & $(2.436)$ & $(0.523)$ & $(1.180)$ & $(0.445)$ \\
\hline \multirow{2}{*}{ Period } & -0.315 & -0.227 & $-0.251 * *$ & $-0.337 * *$ & $-0.385 * * *$ \\
\hline & $(0.369)$ & $(0.327)$ & $(0.104)$ & $(0.165)$ & $(0.102)$ \\
\hline \multirow[t]{2}{*}{ Constant } & $41.810^{* * *}$ & $31.426^{* * *}$ & $9.607 * * *$ & $30.391 * * *$ & $14.304 * * *$ \\
\hline & $(3.376)$ & (3.584) & $(0.918)$ & $(1.685)$ & $(0.903)$ \\
\hline $\mathrm{R}^{2}$ & 0.175 & 0.130 & 0.179 & 0.238 & 0.229 \\
\hline $\begin{array}{l}\text { Subject-period } \\
\text { observations }\end{array}$ & 425 & 425 & 425 & 380 & 380 \\
\hline
\end{tabular}

Note: Standard errors in parentheses are clustered at the subject-level. The models are estimated by ordinary least squares. Risk preferences are measured using the lottery question from the HRS. $* * *$ - significant at $1 \% \quad * * \quad$ - significant at $5 \% \quad * \quad$ - significant at $10 \%$ 


\begin{tabular}{|c|c|c|c|c|c|c|c|}
\hline \multirow[b]{2}{*}{ Variable } & \multicolumn{4}{|c|}{ Limited information treatment } & \multicolumn{3}{|c|}{ Full information treatment } \\
\hline & Beliefs & $\begin{array}{l}\text { Reservation } \\
\text { offers }\end{array}$ & $\begin{array}{l}\text { Correctly } \\
\text { completed } \\
\text { items }\end{array}$ & $\begin{array}{l}\text { Probability } \\
\text { of quitting }\end{array}$ & $\begin{array}{l}\text { Reservation } \\
\text { offers }\end{array}$ & $\begin{array}{l}\text { Correctly } \\
\text { completed } \\
\text { items }\end{array}$ & $\begin{array}{l}\text { Probability } \\
\text { of quitting }\end{array}$ \\
\hline Locus of control & $\begin{array}{l}-0.450 \\
(2.094)\end{array}$ & $\begin{array}{l}0.980 \\
(0.625)\end{array}$ & $\begin{array}{l}0.886 * * \\
(0.388)\end{array}$ & $\begin{array}{l}-0.069^{* *} \\
(0.035)\end{array}$ & $\begin{array}{l}-0.222 \\
(0.735)\end{array}$ & $\begin{array}{l}-0.296 \\
(0.354)\end{array}$ & $\begin{array}{l}-0.038 \\
(0.027)\end{array}$ \\
\hline Risk preferences & $\begin{array}{l}-4.235 * * \\
(1.644)\end{array}$ & $\begin{array}{l}-0.891^{*} \\
(0.526)\end{array}$ & $\begin{array}{l}0.050 \\
(0.364)\end{array}$ & $\begin{array}{l}-0.025 \\
(0.032)\end{array}$ & $\begin{array}{l}-1.032 \\
(0.776)\end{array}$ & $\begin{array}{l}-0.213 \\
(0.386)\end{array}$ & $\begin{array}{l}-0.016 \\
(0.026)\end{array}$ \\
\hline $\begin{array}{l}\text { Optimism- } \\
\text { pessimism }\end{array}$ & $\begin{array}{l}5.101 * * \\
(2.442)\end{array}$ & $\begin{array}{l}1.094 \\
(0.714)\end{array}$ & $\begin{array}{l}0.223 \\
(0.399)\end{array}$ & $\begin{array}{l}-0.015 \\
(0.039)\end{array}$ & $\begin{array}{l}1.160 \\
(0.877)\end{array}$ & $\begin{array}{l}0.286 \\
(0.362)\end{array}$ & $\begin{array}{l}0.030 \\
(0.026)\end{array}$ \\
\hline Self-esteem & $\begin{array}{l}-3.019 \\
(2.734)\end{array}$ & $\begin{array}{l}-0.573 \\
(0.846)\end{array}$ & $\begin{array}{l}-0.332 \\
(0.473)\end{array}$ & $\begin{array}{l}0.006 \\
(0.037)\end{array}$ & $\begin{array}{l}-0.599 \\
(1.090)\end{array}$ & $\begin{array}{l}0.058 \\
(0.413)\end{array}$ & $\begin{array}{l}-0.032 \\
(0.026)\end{array}$ \\
\hline $\begin{array}{l}\text { Big One } \\
\text { (Extroversion) }\end{array}$ & $\begin{array}{l}-6.107 * * * \\
(2.176)\end{array}$ & $\begin{array}{l}-1.219 \\
(0.790)\end{array}$ & $\begin{array}{l}-0.569^{*} \\
(0.333)\end{array}$ & $\begin{array}{l}0.014 \\
(0.035)\end{array}$ & $\begin{array}{l}-0.277 \\
(0.865)\end{array}$ & $\begin{array}{l}-0.775 * * \\
(0.387)\end{array}$ & $\begin{array}{l}0.028 \\
(0.029)\end{array}$ \\
\hline $\begin{array}{l}\text { Big Two } \\
\text { (Agreeableness) }\end{array}$ & $\begin{array}{l}1.673 \\
(2.106)\end{array}$ & $\begin{array}{l}0.775 \\
(0.742)\end{array}$ & $\begin{array}{l}0.654 * * \\
(0.310)\end{array}$ & $\begin{array}{l}0.005 \\
(0.032)\end{array}$ & $\begin{array}{l}-1.968 * * \\
(0.875)\end{array}$ & $\begin{array}{l}0.128 \\
(0.305)\end{array}$ & $\begin{array}{l}0.027 \\
(0.024)\end{array}$ \\
\hline $\begin{array}{l}\text { Big Three } \\
\text { (Conscientiousness) }\end{array}$ & $\begin{array}{l}-5.418 * * \\
(2.224)\end{array}$ & $\begin{array}{l}-0.380 \\
(0.686)\end{array}$ & $\begin{array}{l}-0.455 \\
(0.325)\end{array}$ & $\begin{array}{l}0.024 \\
(0.032)\end{array}$ & $\begin{array}{l}-0.605 \\
(0.802)\end{array}$ & $\begin{array}{l}-0.411 \\
(0.318)\end{array}$ & $\begin{array}{l}0.066^{* * * *} \\
(0.027)\end{array}$ \\
\hline $\begin{array}{l}\text { Big Four } \\
\text { (Emot. Stability) }\end{array}$ & $\begin{array}{l}-1.602 \\
(2.011)\end{array}$ & $\begin{array}{l}-0.262 \\
(0.632)\end{array}$ & $\begin{array}{l}0.214 \\
(0.392)\end{array}$ & $\begin{array}{l}0.084 * * \\
(0.035)\end{array}$ & $\begin{array}{l}-0.594 \\
(0.907)\end{array}$ & $\begin{array}{l}-0.023 \\
(0.296)\end{array}$ & $\begin{array}{l}0.018 \\
(0.020)\end{array}$ \\
\hline $\begin{array}{l}\text { Big Five } \\
\text { (Intellect) }\end{array}$ & $\begin{array}{l}0.115 \\
(2.350)\end{array}$ & $\begin{array}{l}1.597 * * \\
(0.612)\end{array}$ & $\begin{array}{l}-0.331 \\
(0.347)\end{array}$ & $\begin{array}{l}-0.012 \\
(0.035)\end{array}$ & $\begin{array}{l}0.040 \\
(0.650)\end{array}$ & $\begin{array}{l}-0.343 \\
(0.249)\end{array}$ & $\begin{array}{l}0.000 \\
(0.023)\end{array}$ \\
\hline Search cost decile & $\begin{array}{l}-0.761 \\
(0.611)\end{array}$ & $\begin{array}{l}-0.097 \\
(0.224)\end{array}$ & $\begin{array}{l}-0.127 \\
(0.116)\end{array}$ & $\begin{array}{l}0.006 \\
(0.012)\end{array}$ & $\begin{array}{l}-0.509^{*} \\
(0.284)\end{array}$ & $\begin{array}{l}-0.072 \\
(0.111)\end{array}$ & $\begin{array}{l}0.003 \\
(0.008)\end{array}$ \\
\hline Period & $\begin{array}{l}-0.628 * * \\
(0.277)\end{array}$ & $\begin{array}{l}-0.660 * * * \\
(0.080)\end{array}$ & $\begin{array}{l}-0.012 \\
(0.054)\end{array}$ & $\begin{array}{l}0.020 * * * \\
(0.005)\end{array}$ & $\begin{array}{l}-0.662 * * * \\
(0.097)\end{array}$ & $\begin{array}{l}-0.026 \\
(0.044)\end{array}$ & $\begin{array}{l}0.005^{*} \\
(0.003)\end{array}$ \\
\hline Constant & $\begin{array}{l}58.382 * * * \\
(3.544)\end{array}$ & $\begin{array}{l}32.152^{* * * *} \\
(1.252)\end{array}$ & $\begin{array}{l}10.568^{* * *} \\
(0.665)\end{array}$ & & $\begin{array}{l}34.821^{* * *} \\
(1.522)\end{array}$ & $\begin{array}{l}13.448^{* * *} \\
(0.585)\end{array}$ & \\
\hline $\mathrm{R}^{2}$ & 0.126 & 0.140 & 0.062 & 0.085 & 0.150 & 0.058 & 0.086 \\
\hline $\begin{array}{l}\text { Subject-period } \\
\text { observations }\end{array}$ & 1410 & 1410 & 1410 & 1410 & 1287 & 1287 & 1287 \\
\hline
\end{tabular}

Note: Standard errors in parentheses are clustered at the subject-level. The models in columns 1-3 and 4-5 are estimated by ordinary least squares. Columns 4 and 7 report the marginal effects from probit models of the probability of quitting estimated by maximum likelihood. Pseudo- $\mathrm{R}^{2} \mathrm{~s}$ reported for the probit models.

$* * *$ - significant at $1 \% \quad * *-$ significant at $5 \% \quad * \quad$ - significant at $10 \%$ 
Table 11: Estimated marginal effects including achievement scores in preferred specifications

\begin{tabular}{|c|c|c|c|c|c|c|c|}
\hline \multirow[b]{2}{*}{ Variable } & \multicolumn{4}{|c|}{ Limited information Treatment } & \multicolumn{3}{|c|}{ Full information treatment } \\
\hline & Beliefs & $\begin{array}{l}\text { Reservation } \\
\text { offers }\end{array}$ & $\begin{array}{l}\text { Correctly } \\
\text { completed } \\
\text { items }\end{array}$ & $\begin{array}{l}\text { Probability } \\
\text { of quitting }\end{array}$ & $\begin{array}{l}\text { Reservation } \\
\text { offers }\end{array}$ & $\begin{array}{l}\text { Correctly } \\
\text { completed } \\
\text { items }\end{array}$ & $\begin{array}{l}\text { Probability } \\
\text { of quitting }\end{array}$ \\
\hline \multirow[t]{2}{*}{ Locus of control } & 1.026 & 1.291 & 0.571 & $-0.088 * *$ & -0.287 & $-0.606^{*}$ & -0.021 \\
\hline & $(2.460)$ & $(0.822)$ & $(0.377)$ & $(0.041)$ & $(0.783)$ & $(0.357)$ & $(0.025)$ \\
\hline \multirow[t]{2}{*}{ Risk preferences } & -2.803 & $-1.433 * *$ & $-0.742 *$ & $0.062 *$ & -0.925 & -0.125 & -0.004 \\
\hline & (2.124) & $(0.711)$ & $(0.427)$ & $(0.036)$ & $(0.887)$ & $(0.394)$ & $(0.017)$ \\
\hline Optimism- & 2.598 & 0.715 & 0.332 & -0.025 & $1.896^{*}$ & 0.450 & 0.011 \\
\hline pessimism & $(2.411)$ & $(0.770)$ & $(0.417)$ & $(0.043)$ & $(1.029)$ & $(0.430)$ & $(0.025)$ \\
\hline \multirow[t]{2}{*}{ Self-esteem } & -1.749 & -0.337 & -0.564 & 0.021 & -0.370 & 0.080 & -0.029 \\
\hline & $(2.540)$ & $(0.944)$ & $(0.467)$ & $(0.045)$ & $(1.260)$ & $(0.437)$ & $(0.023)$ \\
\hline Big One & $-6.208 * *$ & -1.040 & -0.364 & -0.001 & -0.094 & -0.545 & 0.014 \\
\hline (Extroversion) & $(2.385)$ & $(0.902)$ & $(0.366)$ & $(0.045)$ & $(1.048)$ & $(0.409)$ & $(0.025)$ \\
\hline Big Two & 3.146 & 1.134 & $0.666^{*}$ & 0.020 & $-2.497 * * *$ & -0.232 & 0.043 \\
\hline (Agreeableness) & $(2.147)$ & $(0.792)$ & $(0.362)$ & $(0.038)$ & $(0.920)$ & $(0.323)$ & $(0.028)$ \\
\hline Big Three & $-6.830 * * *$ & -0.610 & -0.376 & 0.011 & -0.968 & 0.098 & $0.037^{*}$ \\
\hline (Conscientiousness) & $(2.418)$ & $(0.860)$ & $(0.364)$ & $(0.034)$ & $(0.903)$ & $(0.315)$ & $(0.021)$ \\
\hline Big Four & 0.334 & -0.271 & -0.127 & $0.132 * * *$ & -1.544 & -0.442 & $0.042 *$ \\
\hline (Emot. Stability) & (2.303) & $(0.739)$ & $(0.443)$ & $(0.044)$ & $(1.005)$ & $(0.356)$ & $(0.022)$ \\
\hline Big Five & -0.979 & $1.306^{*}$ & -0.429 & -0.006 & -0.202 & -0.465 & 0.013 \\
\hline (Intellect) & $(2.547)$ & $(0.729)$ & $(0.422)$ & $(0.041)$ & $(0.761)$ & $(0.288)$ & $(0.021)$ \\
\hline \multirow[t]{2}{*}{ Search cost decile } & -0.716 & 0.016 & -0.060 & 0.013 & -0.462 & -0.208 & 0.009 \\
\hline & $(0.673)$ & $(0.273)$ & $(0.135)$ & $(0.014)$ & $(0.351)$ & $(0.125)$ & $(0.007)$ \\
\hline \multirow[t]{2}{*}{ Achievement score } & 0.948 & -0.729 & $0.909 * *$ & $-0.085 * *$ & 0.335 & $0.988 * * *$ & $-0.052 * * *$ \\
\hline & $(1.970)$ & $(0.787)$ & $(0.364)$ & $(0.039)$ & $(0.740)$ & $(0.340)$ & $(0.018)$ \\
\hline \multirow[t]{2}{*}{ Period } & $-0.719 * *$ & $-0.630 * * *$ & 0.033 & $0.018 * * *$ & $-0.660 * * *$ & -0.031 & 0.003 \\
\hline & $(0.275)$ & $(0.084)$ & $(0.054)$ & $(0.005)$ & $(0.118)$ & $(0.050)$ & $(0.002)$ \\
\hline \multirow[t]{2}{*}{ Constant } & $58.160 * * *$ & $31.400 * * *$ & $10.156^{* * *}$ & & $34.445^{* * *}$ & $14.309 * * *$ & \\
\hline & $(3.683)$ & $(1.446)$ & $(0.761)$ & & $(1.929)$ & $(0.642)$ & \\
\hline $\mathrm{R}^{2}$ & 0.107 & 0.159 & 0.091 & 0.119 & 0.160 & 0.115 & 0.143 \\
\hline $\begin{array}{l}\text { Subject-period } \\
\text { observations }\end{array}$ & 1132 & 1132 & 1132 & 1132 & 1019 & 1019 & 1019 \\
\hline
\end{tabular}

Note: Standard errors in parentheses are clustered at the subject-level. The models in columns 1-3 and 4-5 are estimated by ordinary least squares. Columns 4 and 7 report the marginal effects from probit models of the probability of quitting estimated by maximum likelihood. Pseudo- $\mathrm{R}^{2} \mathrm{~s}$ reported for the probit models. Risk preferences are measured using the lottery question from the HRS. $* * *$ - significant at $1 \% \quad * *$ - significant at $5 \% \quad * \quad$ - significant at $10 \%$ 
Table 12: Estimated marginal effects in the partial information treatment

\begin{tabular}{|c|c|c|c|c|}
\hline \multirow[b]{2}{*}{ Variable } & \multicolumn{4}{|c|}{ Dependent variable } \\
\hline & $\begin{array}{l}\text { Beliefs } \\
\text { (1) }\end{array}$ & $\begin{array}{c}\text { Reservation offers } \\
\text { (2) }\end{array}$ & $\begin{array}{c}\text { Completed items } \\
\text { (3) }\end{array}$ & $\begin{array}{l}\text { Probability of quitting } \\
\text { (4) }\end{array}$ \\
\hline \multirow[t]{2}{*}{ Locus of control } & $-15.664 * *$ & -1.041 & 0.075 & -0.019 \\
\hline & $(5.820)$ & $(1.838)$ & $(0.663)$ & $(0.087)$ \\
\hline \multirow[t]{2}{*}{ Risk preferences } & 0.862 & 0.695 & -0.734 & -0.003 \\
\hline & $(4.684)$ & $(2.082)$ & $(0.514)$ & $(0.089)$ \\
\hline \multirow[t]{2}{*}{ Optimism-pessimism } & $12.299 * *$ & 1.470 & $-2.024 * * *$ & -0.067 \\
\hline & $(6.011)$ & $(1.395)$ & $(0.715)$ & $(0.090)$ \\
\hline \multirow[t]{2}{*}{ Self-esteem } & $16.185^{*}$ & $5.265 * *$ & $2.042 * * *$ & 0.025 \\
\hline & $(8.405)$ & $(2.224)$ & $(0.599)$ & $(0.147)$ \\
\hline Big One & -6.012 & $-3.415^{*}$ & $-0.831^{*}$ & 0.074 \\
\hline (Extroversion) & $(5.613)$ & $(1.796)$ & $(0.475)$ & $(0.088)$ \\
\hline Big Two & 10.955 & 0.700 & -0.297 & 0.141 \\
\hline (Agreeableness) & $(6.845)$ & $(2.658)$ & $(0.564)$ & $(0.106)$ \\
\hline Big Three & 3.058 & -2.329 & -0.295 & 0.042 \\
\hline (Conscientiousness) & $(5.388)$ & $(2.100)$ & $(0.457)$ & $(0.086)$ \\
\hline Big Four & $-12.700 *$ & -0.834 & 0.154 & 0.093 \\
\hline (Emotional Stability) & $(7.225)$ & $(2.008)$ & $(0.687)$ & $(0.129)$ \\
\hline Big Five & -6.036 & -1.858 & $1.026^{* *}$ & -0.125 \\
\hline (Intellect) & $(4.966)$ & $(1.742)$ & $(0.437)$ & $(0.087)$ \\
\hline \multirow[t]{2}{*}{ Search cost decile } & $-2.686^{*}$ & -0.786 & -0.140 & -0.045 \\
\hline & $(1.573)$ & $(0.613)$ & $(0.181)$ & $(0.031)$ \\
\hline \multirow[t]{2}{*}{ Period } & -0.309 & -0.060 & $-0.123^{*}$ & 0.010 \\
\hline & $(0.455)$ & $(0.141)$ & $(0.064)$ & $(0.006)$ \\
\hline \multirow[t]{2}{*}{ Constant } & $69.555 * * *$ & $29.622 * * *$ & $12.075 * * *$ & \\
\hline & $(8.088)$ & (4.117) & (1.108) & \\
\hline $\mathrm{R}^{2}$ & 0.309 & 0.183 & 0.287 & \\
\hline $\begin{array}{l}\text { Subject-period } \\
\text { observations }\end{array}$ & 326 & 326 & 326 & 326 \\
\hline
\end{tabular}

Note: Standard errors in parentheses are clustered at the subject-level. The models in columns 1-3 are estimated by ordinary least squares. The last column reports the marginal effects from the probit model of the probability of quitting estimated by maximum likelihood. Risk preferences are measured using the lottery question from the HRS.

$* * *$ - significant at $1 \% \quad * * \quad$ - significant at $5 \% \quad * \quad$ - significant at $10 \%$ 


\section{Table 13: Estimated marginal effects in Probit models of the probability of "quitting"}

\begin{tabular}{llc}
\hline & \multicolumn{2}{c}{ Marginal effects } \\
Variable & Limited information & Full information \\
\hline Locus of control & $-0.075^{* *}$ & -0.039 \\
& $(0.034)$ & $(0.028)$ \\
Risk preferences & 0.050 & 0.003 \\
& $(0.030)$ & $(0.021)$ \\
Optimism-pessimism & -0.012 & 0.033 \\
& $(0.038)$ & $(0.027)$ \\
Self-esteem & 0.005 & -0.031 \\
& $(0.038)$ & $(0.026)$ \\
Search cost decile & 0.007 & 0.002 \\
& $(0.011)$ & $(0.008)$ \\
Big One & 0.007 & 0.028 \\
(Extroversion) & $(0.035)$ & $(0.027)$ \\
Big Two & -0.003 & 0.025 \\
(Agreeableness) & $(0.032)$ & $(0.026)$ \\
Big Three & 0.026 & $0.066^{* *}$ \\
(Conscientiousness) & $(0.030)$ & $(0.027)$ \\
Big Four & $0.089 * *$ & 0.018 \\
(Emotional Stability) & $(0.035)$ & $(0.020)$ \\
Big Five & -0.010 & -0.001 \\
(Intellect) & $(0.036)$ & $(0.024)$ \\
Period & $0.020^{* * *}$ & $0.005^{*}$ \\
& $(0.005)$ & $(0.003)$ \\
Pseudo-R & & \\
Subject-period observations & 0.095 & 0.083 \\
\hline \hline
\end{tabular}

Note: Standard errors in parentheses are clustered at the subject-level. The probit models are estimated by maximum likelihood. Marginal effects evaluated at sample means. Risk preferences are measured using the lottery question from the HRS.

$* * *$ - significant at $1 \% \quad * * \quad$ - significant at $5 \% \quad * \quad$ - significant at $10 \%$ 


\section{Appendix - For online publication only}

\section{Instructions: Limited Information Treatment}

This is an experiment in the economics of market decision making. The instructions are simple, and if you follow them carefully, you may earn a CONSIDERABLE AMOUNT OF MONEY which will be PAID TO YOU IN CASH at the end of the experiment.

\section{Part 1: Structure}

This experiment is broken up into 2 episodes, and each episode will be broken up into 21 periods. In the first period of both episodes, you will be asked to complete a word coding task, which is explained below in Part 2. The number of items you complete in the word coding task may affect whether or not you receive an offer during a period. Each offer is an amount denominated in an Experimental Currency Unit (ECU), where the exchange rate between dollars and ECUs is $\$ 1=100$ ECUs. If you do not receive an offer or you receive an offer but choose not accept it, you receive 15 ECUs for that period and move on to the next period in which you will again complete the word coding task. If you accept an offer at any point, you receive 15 ECUs for that period and the amount of the accepted offer for every remaining period. In the $21^{\text {st }}$ period, you will only receive ECUs if you have accepted an offer. If you turn down an offer in a period, it is possible that you will not receive another in future periods, but it is also possible that you will receive an offer higher than the one you have turned down. There are 7 possible offers. If you receive an offer, the table below gives the chances that it will be one of these 7 offers.

\begin{tabular}{|l|l|}
\hline Offer & Probability \\
\hline 5 ECU & $0.25-$ or 25 times out of 100 \\
\hline $10 \mathrm{ECU}$ & $0.25-$ or 25 times out of 100 \\
\hline $15 \mathrm{ECU}$ & $0.25-$ or 25 times out of 100 \\
\hline $20 \mathrm{ECU}$ & 0.10 - or 10 times out of 100 \\
\hline $35 \mathrm{ECU}$ & 0.05 - or 5 times out of 100 \\
\hline $40 \mathrm{ECU}$ & 0.05 - or 5 times out of 100 \\
\hline $45 \mathrm{ECU}$ & $0.05-$ or 5 times out of 100 \\
\hline
\end{tabular}

Your earnings will be based on the amounts you receive in each period. Examples:

Ex. 1

You do not receive any offers or you turn down every offer received in the first 20 periods. You will receive 15 ECUs per period for periods 1 through 20 . You will not receive anything in the $21^{\text {st }}$ period because you have not accepted an offer. In this example, the earnings are

\section{$(20 \times 15$ ECUs $)=300$ ECUs}

Ex. 2

You do not accept any offers in periods 1-9. In period 10 you accept an offer of 45 . Your earnings will be 15 ECUs for periods 1 through 10, and 45 ECU for periods 11 through 21 . In this example, your earnings are:

$(10 \times 15$ ECUs $)+(11 \times 45$ ECUs $)=150+495=645$ ECUs

Ex. 3

You turn down an offer of 5 ECUs in period 1 and accept an offer of 20 ECUs in period 2. You earn 15 ECUs for the first 2 periods and 20 ECUs for the remaining 19 periods. Your earnings will be $(2 \times 15$ ECUs $)+(19 \times 20$ ECUs $)=30+380=410$ ECUs 


\section{Ex. 4}

You do not receive offers or you reject all offers received in periods 1 through 16 . In the $17^{\text {th }}$ period you accept an offer of 40 . Your earnings will be 15 ECUs for every period before and including the period in which you accept an offer (irrespective of whether you did not receive an offer or received an offer and turned it down), and the amount you accepted, 40 ECUs, for every period after you accepted your offer through the $21^{\text {st }}$ period. In this example, the earnings are

$(17 \times 15$ ECUs $)+(4 \times 40$ ECUs $)=255+160=415$ ECUs

After you complete the word coding task, but before you see if you have received an offer, you will be asked to answer three questions:

1) How many items do you think you correctly completed?

2) What do you think the probability is that you receive an offer?

3) If you receive an offer in this period, what would the offer have to be for you to accept it?

Answers to the second question should be a number between 0 and 100 , where 0 means "there is a $0 \%$ chance that I will receive an offer," 1 means "there is a $1 \%$ chance that I will receive an offer," and so on up to 100 which means "there is a $100 \%$ chance that I will receive an offer."

After answering the questions, you will learn whether or not you received an offer. If you received an offer, you can choose to either accept the offer and receive that amount for all the remaining periods, or reject the offer and move on to the word coding task in the next period.

In each period before you accept an offer, you will engage in the word coding task, answering questions, and choosing whether or not to accept an offer if you have received one. For the periods after you have accepted an offer, you will be told what the current period is and what your earnings are for that period (i.e., the offer you have accepted). If everyone has accepted an offer, the program will automatically calculate your earnings for the remaining periods and skip to the end of the episode.

\section{Part 2: Word Coding Task}

You will have a maximum of 90 seconds for the word coding task during any period before you have accepted an offer. A key will be given on the top, left-hand side of your screen. This key will pair ten words with ten 4-digit numbers. Below this key will be a list of seven words, each of which is followed by five 4-digit numbers. To complete the task for each word listed, select the 4-digit number that is paired with that word in the key. You can move on to a new set of word-number pairings by clicking the "Next Set" button at the bottom of your screen to complete more items. Although you have a maximum of 90 seconds to complete as many items as you wish in the word coding task, you may stop at any point by clicking on the "Stop" button at the bottom of the screen.

\section{Part 3: Questionnaire}

After completing both episodes you will complete a questionnaire.

\section{Part 4: Payoffs}

At the end of today's session you will receive your earnings from both episodes plus your earnings from part of the questionnaire. In addition, all subjects will receive a $\$ 6$ participation fee.

Are there any questions? 


\section{Instructions: Full Information Treatment}

For this second episode, the probability that you receive an offer will be equal to 0.04 times the number of correctly completed items. If this number is larger than 1 , you will definitely receive an offer. Consider the following examples:

Ex. 1

You correctly complete 12 items. The probability that you receive an offer is $0.04 \times 12=0.48$, or $48 \%$

Ex. 2

You correctly complete 19 items. The probability that you receive an offer is $0.04 \times 19=0.76$, or $76 \%$

Ex. 3

You correctly complete 6 items. The probability that you receive an offer is $0.04 \times 6=0.24$, or $24 \%$

Are there any questions? 


\section{Abbreviated 4-item Rotter Internal-External Locus of Control Scale}

A. What happens to me is my own doing.

B. Sometimes I feel that I don't have enough control over the direction my life is taking.

A. When I make plans, I am almost certain that I can make them work.

B. It is not always wise to plan too far ahead because many things turn out to be a matter of good or bad fortune.

A. In my case getting what I want has little or nothing to do with luck.

B. Many times we might just as well decide what to do by flipping a coin.

A. Many times I feel that I have little influence over the things that happen to me.

B. It is impossible for me to believe that chance or luck plays an important role in my life.

\section{HRS/NLSY79 Risk Preference}

A. Now I have another kind of question. Suppose that you are the only income earner in the family, and you have a good job guaranteed to give you your current (family) income every year for life. You are given the opportunity to take a new and equally good job, with a 50-50 chance that it will double your (family) income and a 50-50 chance that it will cut your (family) income by a third. Would you take the new job?

Yes (go to B)

No (go to $\mathrm{C}$ )

B. Suppose the chances were 50-50 that it would double your (family) income and 50-50 that it would cut it in half. Would you still take the new job?

Yes (go to end)

No (go to end)

C. Suppose the chances were 50-50 that it would double your (family) income and 50-50 that it would cut it by 20 percent. Would you take the new job?

Yes (go to end)

No (go to end)

\section{GSOEP Risk Preference}

Are you generally a person who is fully prepared to take risks or do you try to avoid taking risks? Rate yourself from 0 to 10 , where 0 means "unwilling to take any risks" and 10 means "fully prepared to take risks."

\section{Holt-Laury Low Stakes Risk Preference}

In the questions that follow, you are going to be asked to make ten decisions. Each decision will be between Option A and Option B. Please enter your decisions below and on the corresponding sheet that was handed out to you. Only one of the ten choices you make will be used to determine your earnings for this part of the experiment. After you answer all 10 questions you will be shown the "decision selected" and "outcome" which will be used to calculate your earnings. Be sure to write these down. Each decision is a paired choice between "Option A" and "Option B." You will make ten choices. Before you start making your ten choices, let me explain what these choices mean. 
Imagine a ten-sided die that will be used to determine payoffs; the faces are numbered from 1 to 10 . After you have made all of your choices, the die would be thrown twice, once to select one of the ten decisions to be used, and a second time to determine what your payoff is for the option you chose, A or B, for the particular decision selected. Given this, you should make the choice that you would prefer if we were throwing the die for real. Now, please look at Decision 1 at the top. Option A pays 200 pennies if the throw of the ten sided die is 1 , and it pays 160 pennies if the throw is $2-10$. Option $\mathrm{B}$ yields 385 pennies if the throw of the die is 1 , and it pays 10 pennies if the throw is $2-10$. The other Decisions are similar, except that as you move down the table, the chances of the higher payoff for each option increase. In fact, for Decision 10 in the bottom row, the die will not be needed since each option pays the highest payoff for sure, so your choice here is between 200 pennies or 385 pennies.

To summarize, you will make ten choices: for each decision row you will have to choose between Option A and Option B. You may choose A for some decision rows and B for other rows, and you may change your decisions and make them in any order.

\begin{tabular}{|c|c|c|c|}
\hline & Option A & Option B & $\underline{\text { Your Choice }}$ \\
\hline 1. & $1 / 10$ of $\$ 2.00 \quad 9 / 10$ of $\$ 1.60$ & $1 / 10$ of $\$ 3.85 \quad 9 / 10$ of $\$ 0.10$ & $\mathbf{A} / \mathbf{B}$ \\
\hline 2. & $2 / 10$ of $\$ 2.00 \quad 8 / 10$ of $\$ 1.60$ & $2 / 10$ of $\$ 3.85 \quad 8 / 10$ of $\$ 0.10$ & $\mathbf{A} / \mathbf{B}$ \\
\hline 3. & $3 / 10$ of $\$ 2.007 / 10$ of $\$ 1.60$ & $3 / 10$ of $\$ 3.85 \quad 7 / 10$ of $\$ 0.10$ & $\mathbf{A} / \mathbf{B}$ \\
\hline 4. & $4 / 10$ of $\$ 2.00 \quad 6 / 10$ of $\$ 1.60$ & $4 / 10$ of $\$ 3.85 \quad 6 / 10$ of $\$ 0.10$ & $\mathbf{A} / \mathbf{B}$ \\
\hline 5. & $5 / 10$ of $\$ 2.00 \quad 5 / 10$ of $\$ 1.60$ & $5 / 10$ of $\$ 3.85 \quad 5 / 10$ of $\$ 0.10$ & A / B \\
\hline 6. & $6 / 10$ of $\$ 2.00 \quad 4 / 10$ of $\$ 1.60$ & $6 / 10$ of $\$ 3.85 \quad 4 / 10$ of $\$ 0.10$ & $\mathbf{A} / \mathbf{B}$ \\
\hline 7. & $7 / 10$ of $\$ 2.00 \quad 3 / 10$ of $\$ 1.60$ & $7 / 10$ of $\$ 3.85 \quad 3 / 10$ of $\$ 0.10$ & $\mathbf{A} / \mathbf{B}$ \\
\hline 8. & $8 / 10$ of $\$ 2.00 \quad 2 / 10$ of $\$ 1.60$ & $8 / 10$ of $\$ 3.85 \quad 2 / 10$ of $\$ 0.10$ & A / B \\
\hline 9. & $9 / 10$ of $\$ 2.00 \quad 1 / 10$ of $\$ 1.60$ & $9 / 10$ of $\$ 3.85 \quad 1 / 10$ of $\$ 0.10$ & $\mathbf{A} / \mathbf{B}$ \\
\hline 10. & $10 / 10$ of $\$ 2.00 \quad 0 / 10$ of $\$ 1.60$ & $10 / 10$ of $\$ 3.85 \quad 0 / 10$ of $\$ 0.10$ & $\mathbf{A} / \mathbf{B}$ \\
\hline
\end{tabular}

\section{LOT-R}

Using the response scale provided, let us know how much you agree or disagree with each of the following statements.

$\mathrm{A}=\mathrm{I}$ agree $\mathrm{a}$ lot

$\mathrm{B}=\mathrm{I}$ agree a little

$\mathrm{C}=\mathrm{I}$ neither agree nor disagree

$\mathrm{D}=\mathrm{I}$ disagree a little

$\mathrm{E}=\mathrm{I}$ disagree a lot

In uncertain times, I usually expect the best. 
If something can go wrong for me, it will.

I'm always optimistic about my future.

I hardly ever expect things to go my way.

I rarely count on good things happening to me.

Overall, I expect more good things to happen to me than bad.

\section{Rosenberg Self-Esteem Scale}

Using the response scale provided, let us know how much you agree or disagree with each of the following statements.

\section{Strongly Agree}

Agree

Disagree

Strongly Disagree

I feel that I'm a person of worth, at least on an equal basis with others.

I feel that I have a number of good qualities.

All in all, I am inclined to feel that I am a failure

I am able to do things as well as most other people.

I feel I do not have much to be proud of.

I take a positive attitude toward myself.

On the whole, I am satisfied with myself.

I wish I could have more respect for myself.

I certainly feel useless at times.

At times I think I am no good at all.

\section{Cost Questions}

We would like to get a sense for your opinion of the word matching we had you do. Imagine that you had to complete some items in the word matching task, but you have the option to pay money to be excused from completing some of them. Please tell us how much you would be willing to pay, in dollars, to be excused from different numbers of items. For example, an answer of $\$ 0.01$ means you would pay 1 cent, and an answer of $\$ 2$ means that you would be willing to pay $\$ 2$. Please consider the questions and answer them seriously (i.e. paying $\$ 1$ billion to avoid doing one item seems unlikely). Your answers can vary down to the penny. Raise your hand if you have any questions.

How much would you be willing to pay to avoid completing 4 items? How much would you be willing to pay to avoid completing 8 items? How much would you be willing to pay to avoid completing 12 items? How much would you be willing to pay to avoid completing 16 items? How much would you be willing to pay to avoid completing 20 items? How much would you be willing to pay to avoid completing 24 items? 